\title{
A voltas co uso do artigo nas denominacións toponímicas
}

\author{
Xosé-Álvaro Porto Dapena \\ Universidade da Coruña
}

\begin{abstract}
Resumo:
O obxecto do presente traballo é estudar a natureza e funcións do artigo que nunha grande porcentaxe de casos, tanto en galego coma en español, precede aos nomes de lugar como en A Coruña, Os Peares, El Escorial, Los Monegros. A idea, xeralmente aceptada, de que este artigo forma parte do propio topónimo é tan só certa en contados casos, como son os de Oporto ou Alcalá en español, ou, en galego, Arriba, Ocastro e Acernada, porque, ademais de aglutinarse graficamente co topónimo, xa non se sente nin funciona como verdadeiro artigo. Agora ben, segundo se argumenta nas páxinas que seguen, normalmente o artigo que precede aos topónimos segue funcionando como tal artigo, constituíndo, polo tanto, un vocábulo en si mesmo que, obviamente, non pode interpretarse como constituínte do nome propio a que acompaña. Con este forma o que aquí imos chamar sintagma denominativo, onde tal apéndice gramatical pode desempeñar tres funcións moi distintas: a anafórica (por exemplo, en o Miño, o Pindo, el Ebro), a recategorizadora (así, en a Galicia medieval, el Madrid de los Austrias) e, finalmente, a pleonástica, como, por exemplo, en A Coruña, La Rioja. É certo que, neste último caso, o artigo se acha máis unido ao nome -de aí o costume de escribilo con maiúscula incial-; pero segue comportándose como tal, como o demostra o feito de ser incompatible con outro artigo de carácter anafórico ou recategorizador (por exemplo, en $a$ Coruña de antes da guerra / * a Coruña de antes da guerra), ou que, precedido de certas preposicións, se funde con elas (así, Vai na Coruña, Anda polas Pontes). A conclusión que se tira de todo isto é que o artigo pleonástico é igualmente traducible que, por descontado, o anafórico e recategorizador cando se fala ou escribe nunha lingua diferente á orixinaria do topónimo: Nació en la Mariña, Veño das Batuecas.
\end{abstract}

\section{Palabras chave:}

Artigo, Toponimia, Toponomástica, Lingüística.

\begin{abstract}
:
The object of this work is to study the nature and functions of the article that in a large percentage of cases, both in Portuguese and in Spanish, precedes the names of places such as in A Coruña, Os Peares, El Escorial, Los Monegros. The idea, generally accepted, that this article is part of the place name is only true in rare cases, such as Oporto and Alcalá in Spanish, or Arriba, Ocastro and Acernada in Portuguese, this is due to the fact that apart from blending with the place name, the article no longer is felt or functions as a real article. Nevertheless, as it is stated in the pages that follow, usually the article preceding place names continues to operate as such article and therefore creates a new place name, which cannot be interpreted as part of the name that goes with it. This form which is called here sintagma
\end{abstract}




\begin{abstract}
denominativo (denominative phrase), can play three different grammatical functions: the anaphoric function (eg, in $\mathrm{O}$ Minho, $\mathrm{O}$ Pindo, El Ebro), the function of recategorization (thus, in a Galicia medieval, el Madrid de los Austrias) and finally, the pleonastic one, for example, in A Coruña, La Rioja. Admittedly, in the later case, the article is more linked to the place name-hence the custom of writing it with initial capital letter, but it is still behaving as such, as evidenced by the fact that it is incompatible with another article of anaphoric character or recategorization (eg, in a Coruña de antes da guerra / *a A Coruña de antes da guerra), or preceded by certain prepositions, it merges with them (thus, Vai na Coruña, Anda polas Pontes). The conclusion which follows from all this is that the so called pleonastic article as well as the anaphoric one and the one with the function of recategorization can also be translated both in oral and written forms into a target language, other than the one that originated the place names, therefore: Nació en la Mariña, Veño das Batuecas.
\end{abstract}

Key words:

Article, Toponymy, Toponomastics, Linguistics.

\title{
0. Introdución
}

Recordo que, hai uns anos, o BNG de Cedeira me invitou a unha pequena festa na sede do partido, e alí me atopei cun rapaz - da UPG, segundo me dixo- que me relatou unha singular "fazaña" que tempo atrás protagonizara con motivo dunha visita á Coruña: resulta que, pasando na súa pequena moto pola avenida de Alfonso Molina, observou de súpeto que nun dos xardíns próximos había un letreiro, realizado cos propios elementos vexetais, no que, anunciando a entrada na cidade, dicía La Coruña; sen pensalo nin un intre, aparcou a moto como puido e dispúxose a arrancar o L sen máis, proseguindo a continuación a súa ruta á cidade. Naturalmente, a letra foi restituída de inmediato e a noticia saltou aos xornais, que o atribuíron a unha simple falcatruada "galeguista" sen maior importancia. A cousa, sen embargo, non parou aí, pois o noso "heroe" volveu repetir a fazaña unhas cantas veces máis ata que -claro está- na última ocasión xa o estaba a agardar a policía municipal.

Do que talvez non se decataba entón este rapaz era de que estaba a librar unha batalla máis na que eu chamo "guerra do artigo", a cal, aínda que parecía terse rematado -a prol, claro está, dos que defenden A Coruña- coa oficialización desta forma por parte da Xunta, xorde aínda de cando en vez algunha que outra escaramuza sobre o tema, de xeito que a loita entre os partidarios de A Coruña e os de La Coruña tense convertido nunha especie de lugar común da política municipal coruñesa e parece que non ten visos de rematar xamais.

Sen pretender tomar partido en semellantes disputas -sen dúbida dabondo estériles a causa dunha pouco construtiva postura tanto de tirios como de troianos- e menos, 
dende logo, erixirme en xuíz nunha causa que se me antolla máis política que verdadeiramente lingüística, propóñome nas páxinas que seguen realizar un estudo acerca do uso do artigo cos topónimos, cuestión que apenas foi tratada coa detención que merece non só por estudosos do galego, senón tamén do español. Observemos, entre outras cousas, a este respecto que existe a tendencia a considerar o artigo que precede a topónimos como A Coruña, O Carballiño, As Pontes, Os Canteiros ou, en castelán, La Habana, El Escorial, Las Batuecas, Los Monegros, como parte integrante do topónimo, o que explica o xeneralizado costume de representalo graficamente tamén con maiúscula. No presente artigo, porén, propóñome presentar algúns argumentos que, ao meu ver, contradín semellante apreciación, sempre, naturalmente, que se parta, como vou facer eu aquí, dun concepto estrito de 'topónimo', é dicir, entendido como nome propio de lugar e non, segundo se tende a pensar con frecuencia, como calquera tipo de denominación referida a unha realidade xeográfica.

\section{Algunhas distincións básicas}

Cómpre, pois, partir dunhas distincións básicas sobre as que vou fundamentar a miña argumentación: por unha parte, entre topónimo e corónimo, que, en relación cos nomes de lugar, é a mesma que existe entre nome propio e común, e, por outra, entre topónimo e sintagma denominativo.

\subsection{Topónimo / corónimo}

Que non todo nome indicador dun lugar ou espazo xeográfico constitúe un topónimo podemos observalo no feito de que toda lingua dispón dun léxico, máis ou menos amplo, relativo a realidades xeográficas (pénsese, por exemplo, en cidade, río, illa, monte, cabo, etc.) que, utilizados en condicións normais, ninguén se atrevería a clasificar como topónimos. Trátase dos chamados corónimos, que son nomes comúns e ademais pertencen ao léxico estruturado da lingua, pois forman paradigmas ou subparadigmas como, por exemplo, no caso de cidade / vila / aldea / casal / rueiro..., todos eles relativos ao campo léxico 'lugar habitado'. Fronte a eles, hai que situar os topónimos, representados sempre por nomes propios do tipo Galicia, Lugo, Fisterra, Toledo, e que, por outra banda, non constitúen -contra o parecer por certo de M. Trapero ${ }^{1}$ - ningún paradigma léxico, pasando a conformar dunha simple lista ou repertorio, é dicir, dunha nomenclatura que, se ben pode presentar certas

1 Este autor propón un estudio da toponimia aplicando os principios e métodos da lexemática de Coseriu. Véxase M. Trapero (1999: 53 e ss). 
variacións dunha lingua a outra, adoita ter carácter interidiomático en grande parte dos $\operatorname{casos}^{2}$.

Isto suposto, a distinción topónimo / corónimo vén ser a mesma que existe entre nome propio e nome común, cuestión que, como é ben sabido, fixo verter bastante tinta e que, de por si, daría materia para escribir un libro enteiro, naturalmente un máis xunto aos xa existentes ${ }^{3}$. Non vou entrar aquí, polo tanto, en toda a problemática que semellante distinción implica. Limitareime, en todo caso, a observar que a diferenza fundamental entre ambos os dous tipos de nome estriba en que, sincronicamente considerados, o nome común posúe significado, que é precisamente o que fai posible a súa pertenza a un paradigma léxico, mentres que o nome propio carece del -de aí que non forme parte propiamente do léxico- e para o único que serve é para conectar directamente cunha realidade concreta. Dito doutro xeito, a distinción non funciona propiamente na lingua, senón na súa realización discursiva, o que quere dicir que un nome non é común nin propio ata que se realiza no discurso, porque é no modo de referirse ás cousas onde en realidade reside a diferenza: o nome común, ao referirse á realidade, faino indirectamente, a través do significado ou concepto a el asociado e, por iso, dicimos que serve para caracterizar ou clasificar esa realidade que lle serve de referencia - pon de manifesto todos os trazos ou notas que na lingua definen a clase a que esa realidade pertence-, mentres que o nome propio, polo seu lado, serve unicamente para conectar de forma directa cunha realidade sen mostrar para nada ningunha das súas notas ou características, nin sequera, por suposto, a clase a que pertence. Se partimos, efectivamente, dunha forma como rúa, tanto pode funcionar como nome común, co significado de 'vía pública urbana', na súa

2 Así, por exemplo, Madrid é seguramente unha forma toponímica invariable -só na escritura, claro está-en practicamente todas as linguas do mundo; pero non acontece, sen ir máis lonxe, o mesmo con España, que en inglés é Spain, en alemán Spanien, francés Espagne, etc. Dende logo, cando se trata de topónimos estranxeiros ou formados a partir dunha lingua distinta, aínda que, en xeral, é perfectamente lexítimo mantelos na súa forma orixinaria, en moitos casos unha mínima acomodación fónica parece necesaria e imprescindible; pensemos, por exemplo, no caso de que a lingua recipiendaria careza dalgún fonema ou son da lingua orixinaria correspondente ao topónimo; por iso, en galego, non tería moito sentido pronunciar Argentina, á forma castelá, en vez de Arxentina, como tampouco, á recíproca, non parece xusto esixir a un castelán de Valladolid que pronuncie Sanxenxo como nós, pois tenderá a dicir Sansenso, que non existe, ou, como parece máis obvio, a utilizar o tan deostado Sanjenjo, que, aínda que non teña carácter oficial e aos galegofalantes nos soe a diaños, existe realmente no uso. Hai que recoñecer, porén, que é esta unha cuestión delicada e de solución non sempre sinxela e que, polo tanto, merecería un estudo independente.

3 Sen pretensións de exhaustividade, considérense, por exemplo, M. Ariza (1993), E. Bajo Pérez (2002), Burge (1973), T. E. Carratalá García (1975), E. Coseriu (1967²), M. T. Díaz Hormigo (1998), M. J. Fernández Leborans (1999), C. García Gallarín (1998), A. Gardiner (1940), M. N. Gary Prieur (1994), K. Jonasson (1994), G. Kleiber (1992), A. López García (1985 e 2000), B. Migliorini (1968), J. Molino (1982), J. R. Morala (1986), E. Pulgram (1984). 
referencia a calquera realidade así clasificable, como propio, podendo neste caso referirse a calquera obxecto, isto é, con independencia da clase a que pertenza: pode tratarse, efectivamente, dun lugar como en A Rúa de Petín, dunha persoa así apelidada ou, en principio, de calquera outro tipo de realidade sen máis limitacións que as impostas polos usos, gustos ou costumes de cada momento. Isto último é especialmente claro, por exemplo, cando se trata de elixir un nome para un recén nacido. Digamos, en fin, que a utilización dun nome común para denominar un obxecto implica unha clasificación previa -ou adscrición a unha clase ou categoría- dese obxecto concreto, mentres que a aplicación dun nome propio é libre -non vén condicionado pola lingua-e directa: nós chamamos león a un animal que posúe unhas determinadas características, as da clase 'león', polas que non pode entrar, por exemplo, na clase 'can'; pero, independentemente diso, podemos bautizar co nome de León un can concreto ou, pola contra, chamar Can a un determinado león.

Agora ben, dicir que un nome propio carece de significado non equivale a afirmar que careza de motivación semántica, que é outra cousa. A motivación está clara, por exemplo, na creación de alcumes ou sobrenomes, que sempre poñen de relevo algún trazo ou feito que teña que ver coa persoa así chamada, o que nos permite cualificar -e ata celebrar ás veces- o grao de acerto ou desacerto dun determinado alcume. E en toponimia, como é sabido, constitúe precisamente o principal punto de atención non só, evidentemente, por parte dos estudosos desta materia, senón mesmo dos usuarios da lingua en xeral, que senten sempre curiosidade por saber a orixe dos nomes dos seus respectivos pobos ou aldeas. Os nomes propios posúen, en efecto, un significado etimolóxico, o cal pode resultar máis ou menos claro aos falantes -de aí por certo a distinción entre topónimos opacos e transparentes que se vén facendo frecuentemente nos nomes propios de lugar-, pero non fai falta insistir en que o devandito significado nada ten que ver co funcionamento lingüístico deses nomes á hora de se conectar coa realidade designada: ninguén chama Uxío a unha persoa porque pense que é un "ben nacido", nin, por suposto, ninguén pretende chegar á fin da terra cando di que vai a Fisterra. O significado etimolóxico, en todo caso, pode crear certas connotacións - positivas ou negativas- en torno ao nome propio; de aí que un poida sentirse máis ou menos -ou, simplemente, nada- orgulloso do significado do seu nome de pila ou apelido, ou da denominación do lugar onde vive: sempre será máis agradable apelidarse Cortés, Garrido ou Ledo que non Feo, Gordo ou Porca, poñamos por caso, e vivir nun sitio chamado A Marabilla ou O Paraíso e non en Monfero, $O$ Toxo ou $O$ Inferniño.

A distinción, con todo, entre topónimos e corónimos pode en ocasións amosar problemas, pois non hai que esquecer que, como veremos máis adiante, moitos topónimos teñen a súa orixe en corónimos, de maneira que a dificultade está en 
determinar en qué momento estes se fan nomes propios e se converten, polo tanto, en verdadeiros topónimos. Como xa sinalei nalgunha ocasión ${ }^{4}$, os veciños de Cedeira refírense con frecuencia a esta coa denominación de $a$ vila, que, evidentemente, pode interpretarse como corónimo, posto que, efectivamente, alude a unha realidade clasificable como vila, pero ao mesmo tempo non hai dúbida de que semellante denominación se utiliza con finalidade identificativa, cousa evidente cando, como acontece con frecuencia, se refire máis especificamente tan só a unha parte -a máis antiga- da zona urbana cedeiresa.

\subsection{O sintagma denominativo}

Pero isto lévame máis ben a ocuparme dun novo concepto que, ao meu xuízo, tampouco se debe confundir co de 'topónimo', que é o de sintagma denominativo. En realidade unha expresión como a vila para referirse a Cedeira, o mesmo que a ría de Arousa ou o monte Pindo son sintagmas denominativos, que, ao igual que os topónimos, se caracterizan por teren función referencial e poden estar constituídos tan só por un corónimo ou topónimo precedidos de artigo (ou determinante que o inclúa) e, en xeral, por calquera conxunto de palabras que sirvan para nomear un obxecto calquera. Digo máis: un corónimo -e mesmo ás veces un topónimo- está incapacitado para desempeñar por si mesmo a función referencial, función que soamente adquire cando pasa a formar parte dun sintagma denominativo. Así pois, máis que da oposición topónimo / corónimo -ou, máis xeralmente, nome propio / común- do que hai que falar é da oposición nome propio / sintagma denominativo, ou, máis concretamente, topónimo / sintagma denominativo toponímico. Precisamente á confusión destas dúas últimas nocións débese a tendencia -bastante xeneralizada-a crer que o artigo que acompaña a certos topónimos é parte integrante destes, o que leva a escribir o devandito artigo con maiúscula inicial ${ }^{5}$. Evidentemente, considerar o artigo como parte integrante do topónimo -isto é, dun nome propio de lugarequivalería a aceptar, como algunha vez se ten proposto para o español, o carácter morfemático deste apéndice gramatical ou polo menos, como sostén F. Lázaro Carreter (1975), de "signo intermedio" ao morfema e a palabra. Pero desta cuestión ocupareime no seguinte apartado.

En conclusión, chamo denominación a toda expresión con función referencial ou, o que é o mesmo, identificativa, expresión que pode estar constituída por un nome, denominado nese caso nome propio, o cal, cando ten como referencia un lugar, se chama topónimo, ou por toda unha frase ou conxunto de palabras enlazadas

4 Véxase Porto Dapena (2008: 87).

5 A propia RAE na súa última Ortografía de la lengua española (1999: 34) observa que "cuando el artículo forme parte del nombre propio, ambas palabras comenzarán por mayúscula". 
sintacticamente, e entón propoño falar de sintagma denominativo, o cal, por outra banda, pode ter ou non carácter fixo. E así, por exemplo, un título como Os vellos non deben namorarse é un sintagma denominativo con carácter fixo (non un nome propio como ás veces se pensa ${ }^{6}$ ), así como o son tamén, entre outros, A Coruña, O Parrote, Os Peares, S. Andrés de Teixido, ou rio Tambre, a ría de Ortigueira, rúa Federico Tapia ou, mesmo -aínda que sen carácter fixo-, o mestre, os alumnos desta facultade, o pai de Antón, etc., porque todas estas expresións teñen por obxecto a identificación doutras tantas realidades nunha situación concreta. Observemos, finalmente, que o topónimo, como palabra que é, pode ser á súa vez morfoloxicamente simple, como Lugo, Vigo, Sillobre, e composto como Caldas de Reis, Baños de Molgas ou Toxos Outos, unhas veces de carácter analítico como estes últimos, e outras sintético como Campolongo, Pontevedra ou Pontedeume.

As dificultades poderían xurdir á hora de distinguir un topónimo composto de tipo analítico respecto dun sintagma denominativo toponímico; pero a este respecto convén sinalar que este último se caracteriza por ir sempre precedido por un artigo ou determinante, de modo que, mentres Vilagarcía de Arousa é un topónimo, As Pontes de García Rodríguez constitúe un verdadeiro sintagma constituído polo artigo as seguido do topónimo composto Pontes de García Rodríguez. É, polo tanto, o artigo peza fundamental na constitución do sintagma denominativo, no que convén ter, ademais, presente que, como veremos, non sempre desempeña idénticas funcións.

\section{2. $O$ artigo, compoñente do sintagma denominativo}

Como dixen máis arriba, para que un artigo se puider considerar parte dun topónimo -e, en xeral, de calquera tipo de nome-, habería que partir do suposto de que se trata dun morfema nominal, como o xénero e número, posición que, a pesar de ter defensores, carece, ao meu modo de ver, de verdadeiro fundamento en español -e o mesmo en galego-, como hai anos puxen de manifesto ${ }^{7}$. Segundo creo ter demostrado entón, o artigo -se prescindimos dalgúns casos excepcionais, como os do romanés ou do danés, por exemplo- constitúe, malia o seu carácter claramente gramatical e funcional sempre como elemento adxunto dun substantivo,

6 É evidente que un título, pese ao seu frecuente emprego con función identificativa, non constitúe ningún nome propio, pois, entre outras cousas, ten significado (pretende dalgunha maneira indicar o tema ou resumir o contido dunha obra, capítulo, noticia, película, etc.) e pode estar constituido por toda unha oración ou enunciado que, malia responder á "técnica do discurso", pasa, unha vez establecido, a ter carácter fixo. E esta é a razón pola que, gráficamente, se adoita distinguir do resto do texto en que se insire mediante maiúsculas, tipo especial de letra ou comiñas.

7 Véxase Porto Dapena (1985). 
unha verdadeira e auténtica palabra, no que coincido, como é sabido, coa inmensa maioría dos nosos gramáticos. E hei de engadir que nin sequera me parece aceptable a postura salomónica consistente en ver nel un signo intermedio ou a cabalo entre o morfema e a palabra. Dada a importancia do asunto, voume permitir repetir aquí as principais liñas da miña argumentación.

\subsection{O artigo como morfema ou palabra a medias}

Aínda que a consideración do artigo, en español, como mero morfema flexional ou "accidente" do substantivo pode remontarse ao século XVII con G. Correas, cando na súa Arte de la lengua castellana (1954: 139) di:

Nonbre es aquella palabra i boz con que se nombra cada cosa, i tiene xéneros, artículos, números, casos o diferencia de casos con preposiziones,

en realidade os que a puxeron en circulación en tempos modernos foron R. Lenz (1935³: 172) e, sobre todo, E. Alarcos (1970: 168, e 1994: 66). Segundo o primeiro, o artigo non sería máis que "un anexo formal del sustantivo, parecido a las terminaciones flexivas o aglutinadas", sen importar que se escriba separado ou entre en fusión fonética co substantivo. E de acordo co segundo, trataríase dun morfema gramatical cuxo status non difire do dos morfemas de número; o que acontece é que esa situación se vería escurecida polo feito de que, ortograficamente, artigo e substantivo se escriben separados, coma se de palabras distintas se tratar.

Máis cautos móstranse J. Lyons (1975: 211) e F. Lázaro Carreter (1975: 50-51 e 58), quen, partindo dos criterios establecidos por R. H. Robins (1971: 243-248) para a segmentación da cadea falada en palabras, observan que, efectivamente, o artigo non cumpre todas as condicións impostas por este autor, o que non significa que se deba considerar como un simple morfema, senón máis ben como unha palabra non plena ou fronteiriza.

Debo lembrar que as condicións establecidas por R. H. Robins para que un segmento se poida considerar palabra son tres: a) estabilidade interior, isto é, a imposibilidade de reordenar os seus elementos compoñentes, xa que estes ofrecen sempre unha orde fixa (por exemplo, cogumel-o-s non se pode reordenar como ${ }^{*} O$-S-cogumel ou *o-cogumel-s); b) mobilidade posicional dentro da frase (así,

Sabela traballa aqui / Aqui traballa Sabela / Traballa Sabela aqui), 
e, por último, c) separabilidade, é dicir, a posibilidade de que entre dúas palabras contiguas sempre se pode introducir un novo segmento fónico (por exemplo, na secuencia

cidade antiga

pode intercalarse moi:

cidade moi antiga).

Pois ben, aplicando estes criterios ao artigo español, teriamos que este, segundo Lázaro Carreter, cumpriría a primeira e última desas condicións, pero non a segunda: a primeira porque, para este autor, o artigo estaría constituído por un único morfema e, polo tanto, non admitiría ningunha outra ordenación interna, e a última porque entre artigo e substantivo cabe sempre a posibilidade de introducir outro segmento; non admitiría, en troques, a segunda porque o artigo ha de ir sempre diante do substantivo, ten unha posición fixa respecto a este. $\mathrm{O}$ mesmo razoamento podería valer tamén para o galego: en o peixe podemos introducir, entre artigo e substantivo, abundante (o abundante peixe), pero non é posible *peixe o.

O razoamento de Lázaro parece correcto, pero non é satisfatorio. E non é satisfatorio porque non resulta científico nin metodoloxicamente aceptable falar de palabras a medias, como tampouco o sería admitir a existencia de, por exemplo, semi-morfemas ou cuasi-oracións. O que, dende logo, parece claro é que o artigo non constitúe de ningún xeito un morfema e se, por outro lado, non cumpre as condicións para ser palabra, unha de dúas: ou se está a partir dun concepto excesivamente restrinxido de 'palabra' ou, definitivamente, haberá que postular a existencia dun nivel de unidades intermedio ao morfema e á palabra; do que non pode falarse é de palabra non plena, imperfecta ou a medias.

En realidade, se tanto Lyons como Lázaro non se atreven a clasificar o artigo como verdadeira palabra é porque sobre eles pesa, ademais dos criterios de Robins, a definición bloomfieldiana de palabra como "minimal free form", definición na cal non entraría o artigo nin outros signos gramaticais - preposicións, conxuncións ou pronomes átonos - considerados tradicionalmente como tales palabras. Tal é precisamente a razón de que o propio F. Lázaro suxira timidamente a conveniencia de eludir a definición de Bloomfield e restrinxir, por outro lado, as condicións de Robins a tan só a primeira e a terceira, facendo caso omiso da permutabilidade ou mobilidade posicional. Notemos, non obstante, que isto último sería inviable, pois iso levaríanos a aceptarmos como palabras os elementos - por ser separables e posuír cada un estabilidade interior- de vocábulos como libr-o en español 
(temos libr-it-o) ou de pedr-a en galego (son posibles pedr-iñ-a ou pedr-eir-a, por exemplo).

\subsection{O artigo como palabra}

Ha de considerarse, non obstante, correcta a decisión de abandonar a definición bloomfildiana de 'palabra' polo simple feito de que, en efecto, tan só unha parte -a maioría sen dúbida- dos vocábulos tradicionais poden efectivamente constituír enunciados por si mesmos ou, o que é o mesmo, son verdadeiras "formas libres mínimas"; pero ao seu lado hai outras -entre elas o artigo- que non cumpren esa condición. O que, ao meu xuízo, define verdadeiramente a palabra non é a súa capacidade de formar enunciados por si mesma, senón o feito de posuír o que Coseriu chama "significado categorial" ou, o que vén ser o mesmo, o pertencer a unha categoría léxico-gramatical, e neste sentido o artigo constitúe unha verdadeira palabra, pois que forma parte dunha categoría, a dos determinantes, e mesmo, como é sabido, para toda unha longa tradición, constitúe unha categoría en si mesma ou independente.

Pero para que non se me acuse de querer levar a auga ao meu muíño, creando á miña conveniencia unha definición de 'palabra' que abranga tamén o artigo, vou enfocar a miña argumentación doutro xeito prescindindo de calquera definición previa e observando, por outro lado, que tanto pola súa constitución morfolóxica coma polo seu comportamento sintáctico os artigos español e galego se achan necesariamente nun nivel superior ao morfema, nivel que non pode ser outro que o da palabra.

Para empezar e enlazando co razoamento de Alarcos, penso con Lyons (1975: 211) que o caso do artigo español -e o mesmo cabe dicir do galego- non é equiparable ao doutras linguas como o danés e o romanés, onde, efectivamente, parece que funciona como verdadeiro morfema flexional, ao vir representado por un sufixo. Sería precisamente a posición posposta - como observa A. Martinet (1978: 210)- o que facilitaría a súa fusión morfolóxica co substantivo, fronte á anteposición, que, pola contra, facilita a independencia do artigo. E isto é xustamente o que acontece tanto en español como en galego, o que, por outro lado, quere dicir que a ortografía neste caso, lonxe de falsear un feito lingüístico, o que fai é poñelo de manifesto. Non resulta, polo demais, nada estraño que o expresado morfematicamente nunha lingua o sexa léxica ou sintacticamente noutra, e isto é o que realmente acontece co artigo.

Repito que se poden ofrecer argumentos suficientemente sólidos e concluíntes para demostrar que tanto o artigo español como o galego constitúen verdadeiras palabras. Existen, como dixen antes, argumentos morfolóxicos e sintácticos, que se poden resumir así: 
a) En primeiro lugar, o artigo podería considerarse como mero morfema flexional só no caso de que non ofrecese variacións, ou ben que estas puidesen empregarse indistintamente -é dicir, que estivesen en distribución libre- ou viñesen condicionadas polo contexto fonolóxico ou morfolóxico (distribución complementaria). Condicionamento fonolóxico dáse, efectivamente, no caso do español, entre as formas el e la referidas a substantivos femininos, posto que o uso de ambas as dúas formas depende de que o substantivo que siga inmediatamente ao artigo empece ou non por $a$ acentuado. Condicionamento -fonolóxico e morfolóxico á vez- existe tamén en galego a propósito das formas con $l$ - inicial ou sen ela. Pero fóra destes casos, o uso das diversas formas do artigo vén condicionado polos contidos de xénero e número do substantivo, é dicir, responde a un fenómeno de concordancia, paralela á que se produce entre un substantivo e o adxectivo que o acompaña. De aí por certo que, en moitos casos, o artigo actúe, indirectamente, como único indicador do xénero e número no sintagma nominal (así, en español las tesis, ou en galego os venres) ata o punto de que algunha vez se teña chegado a definir como a palabra que se antepón ao nome para indicar o seu xénero e número.

b) Notemos, non obstante, que o feito de que o artigo presente distintas formas para a concordancia co substantivo -e nin sequera que se trate dunha verdadeira palabra - é suficiente para invalidar á súa vez o seu posible carácter morfemático, pois, efectivamente, poderíase tratar dun morfema nominal, aínda que non ligado, senón con carácter libre, é dicir, constituíndo á súa vez unha palabra, como acontece, por exemplo, coas preposicións. Na gramática española hai, en efecto, ademais de Alarcos, outros autores que se inclinan a prol desta consideración como morfema: o propio Lázaro Carreter é un deles e o mesmo pensa C. Hernández Alonso (1985: 115 e ss.). A realidade, non obstante, é moi outra, habida conta de que o artigo español é perfectamente analizable en varios morfemas, a saber: $1^{\circ}$ ) un morfema básico, /el/ e /1/ en distribución complementaria, encargado de expresar o contido 'artigo'; $2^{\circ}$ ) un morfema de xénero, representado por $\varnothing$ e /o/ para o masculino, $\varnothing$ e /a/ para o feminino e /o/ para o neutro, e, finalmente, $3^{\circ}$ ) un morfema de número, $\varnothing$ para o singular e /s/ para o plural. A mesma análise pódese facer do artigo galego, coa diferenza de que neste o morfema básico presenta as variantes ou alomorfes, $\varnothing, / 1 /$ e o practicamente desaparecido /el/.

c) Outro argumento que podemos opoñer á consideración do artigo como mero morfema nominal é que, nese caso, viría a ter carácter prefixal - por se tratar dun constituínte máis do substantivo- o que significaría que, nun sintagma nominal, calquera complemento non incidiría sintacticamente tan só sobre o substantivo, senón sobre o conxunto artigo + substantivo, o que quere dicir que a análise 
de, por exemplo, las ovejas blancas ou, en galego, as ovellas brancas, tería a seguinte representación:

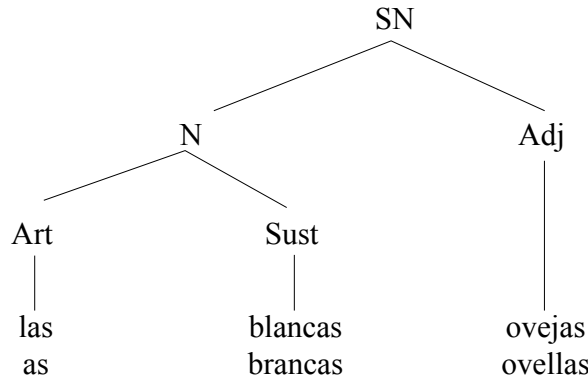

O cal podería ser aceptable se non for que o adxectivo, en lugar de se colocar, na súa función de epíteto, diante do artigo, pasa a ocupar o lugar intermedio entre substantivo e artigo, que, polo tanto, lonxe de ser un constituínte inmediato do substantivo, éo en realidade do sintagma incidindo sobre o grupo constituído polo substantivo e mais o adxectivo; así,

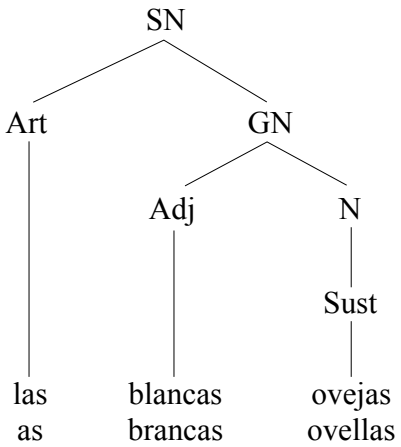

d) E isto, precisamente, sérveme para enlazar cun novo argumento, representado polo feito de que o artigo non só precede a substantivos de lingua, senón tamén de discurso, compostos por todo un sintagma ou mesmo unha oración; por exemplo:

O que non esteas de acordo comigo non impide que sexamos amigos Estou máis cansado do que ti pensas. 
Pois ben, ¿dende cando -cabe preguntármonos- un morfema flexional pode actuar como modificador de toda unha oración ou conxunto de palabras? Pola contra, un modificador deste tipo ten que ser como mínimo unha palabra.

e) Partindo, finalmente, dos tres criterios de Robins, que en realidade se reducen a dous, posto que o primeiro e o terceiro son practicamente o mesmo ${ }^{8}$, pode aceptarse que todo segmento mínimo separable e permutable é unha palabra, o que non quere dicir que toda palabra teña que cumprir a segunda condición. Basta, loxicamente, con que sexa separable mediante un segmento que si sexa separable e permutable á vez, isto é, que constitúa con toda seguridade unha palabra, pois é evidente que unha palabra nunca pode intercalarse dentro doutra. Todo isto quere dicir que, se entre o artigo e o substantivo se pode introducir, por exemplo, un adxectivo, como no caso de as [brancas] ovellas, ambos os dous elementos constitúen palabras independentes morfoloxicamente falando.

\section{Compatibilidade entre topónimos e artigo}

Visto todo o anterior, o artigo é por si mesmo unha palabra e, como tal, pertencerá a unha categoría, que, ao meu ver, non pode ser outra que a dos pronomes -entendidos estes como palabras gramaticais con función nominal ${ }^{9}-\mathrm{e}$, dentro deles, á subcategoría dos determinantes, pois, como estes, anteponse sempre a un substantivo ou expresión equivalente. Por outra banda, como é ben sabido, dende o punto de vista diacrónico, o artigo non vén ser outra cousa que un demostrativo desposuído do seu contido localizador, o que explica, por exemplo, a súa incompatibilidade cos demostrativos cando estes van en posición antenominal, situación en que inclúen a función actualizadora xunto coa idea de 'unicidade' propias do artigo ${ }^{10}$. A súa incompatibilidade -polo menos en principio- esténdese así mesmo aos nomes

8 En ambos os dous alúdese á permutabilidade, vista dende dúas perspectivas: dende dentro da palabra (imposibilidade de permutar os seus elementos constituíntes) e dende fóra (posibilidade de permutar con outras palabras). Agora ben, isto significa exactamente que un segmento permutable nunca poderá interpretarse como constituínte ou parte dunha palabra; pero non que esta teña que ser necesariamente permutable nin, xa que logo, que todo segmento permutable constitúa unha única palabra: en, por exemplo,

\section{O can non roeu o óso}

os elementos permutables son o can, non roeu, o óso, os cales, mentres non se demostre o contrario, están constituídos por cadanseu par de palabras.

9 Véxase Porto Dapena (1986: 7).

10 Isto explica, por certo, a neutralización ou igualación semántica de el / aquel en español e $o$ / aquel en galego en contextos como

Cómpre pensar naqueles que non teñen ren = Cómpre pensar nos que non teñen ren. 
propios en xeral, pois estes tamén inclúen os contidos de actualización e unicidade, aínda que logo, como imos ver, o artigo apareza de feito con eles en múltiples ocasións.

\subsection{O artigo é, en principio, incompatible cun topónimo}

Non vou entrar aquí, obviamente, na tan debatida cuestión acerca do trazo ou trazos semánticos que o artigo achega ao sintagma nominal e, polo tanto, mediante os que se caracteriza fronte a outros determinantes. Lonxe queda xa a vella postura tradicional, segundo a cal o artigo se caracterizaría por indicar o carácter definido ou determinado do obxecto representado polo substantivo a que acompaña e, dende logo, tampouco parece hoxe totalmente aceptable a doutrina que basea a caracterización na idea do 'consabido'. Máis acertada resulta sen dúbida a postura -xeralmente aceptada na actualidade-segundo a cal o artigo sería un actualizador, é dicir, un elemento gramatical mediante o cal un substantivo pasa do plano meramente conceptual, esencial ou virtual ao actual ou existencial, conectándose cos obxectos da realidade ${ }^{11}$.

Segundo E. Coseriu, o artigo viría a ser o actualizador puro, pero en realidade, ao meu xuízo, á súa función actualizadora engade un contido moi importante, que é o de 'unicidade'. Cando, por exemplo, lle dicimos alguén

\section{O cura da miña parroquia non é galego,}

a verdade é que non nos estamos a referir a unha persoa necesariamente coñecida -e, polo tanto, consabida, como dirían algúns- do oínte, quen nin sequera ten por que saber se na miña parroquia hai cura ou non. Agora ben, a utilización do artigo ten aquí un claro significado presuposicional: que na miña parroquia hai só un cura, o que quere dicir que estou a apuntar a un ser único, isto é, con independencia de que pertenza a unha determinada clase ou conxunto, e, polo tanto, totalmente identificado ou, mellor dito, identificable.

Por iso poderiamos dicir con E. Alarcos (1970: 175), que o artigo desempeña a función transpositora de converter un substantivo común, isto é, de clase, en nome propio ou identificador; utilizando o seu mesmo exemplo, serían, polo tanto, equivalentes as expresións

Son juguetes del niño = Son juguetes de Juanito.

11 Véxase E. Coseriu (1969: 293). 
A todo isto cómpre engadir que "único" non debe entenderse no sentido cuantitativo equivalente a 'singular', pois, como é obvio, o artigo tamén precede a substantivos en plural, equivalendo neste caso á totalidade, totalidade como algo único -non oposto a outros da mesma especie- nun determinado contexto ou situación. Por iso se dicimos

\section{Os curas da miña parroquia non son galegos}

non só estaremos afirmando que na nosa parroquia hai varios curas, indicación que vén dada polo morfema cuantificador de plural, senón que a "todos eles" -é dicir, como conxunto único- lles corresponde o predicado. Tan identificador é, polo tanto, o artigo no seu uso singular como plural.

Agora ben, tendo todo isto en conta, o artigo -por definición- deberá acompañar sempre a substantivos comúns ou de clase, xa que estes son os únicos nomes que, nas linguas románicas -non así en latín-, non están normalmente capacitados para desempeñar por si mesmos a función designativa, denominativa ou identificadora. Por todo iso podería resultar chocante o feito de que, a pesar de todo, o artigo aparece ás veces acompañando a un nome propio de persoa -por exemplo nunha sentenza xudicial- e, dende logo, con bastante frecuencia, diante de topónimos. En relación con estes últimos, son múltiples os gramáticos tanto do español como do galego que se ocuparon do tema e ofrecen, a este respecto, toda unha casuística máis ou menos detallada. Así, tan só por citar algúns casos máis representativos, para o español ocupouse do asunto xa A. Bello na súa famosa gramática (ed. 1972, §§ 869-871), máis recentemente Alcina-Blecua na súa Gramática española (1975: 563) e agora a Gramática descriptiva del español, dirixida por I. Bosque e V. Demonte (2000: passim), así como, para o galego, cabe citar ante todo a completísima Gramática da lingua galega. II: Morfosintaxe de X. R. Freixeiro Mato (2000: 267-270). Non fai falta sinalar que en todos estes casos o uso do artigo con nomes propios de lugar se ve, dende logo, como algo excepcional sen que, por outro lado, se afonde nas orixes ou posibles motivos de tal uso así como tampouco nas distintas funcións que $\mathrm{o}$ artigo presenta de feito en tales circunstancias.

\subsection{As distintas clases de artigo: topónimos con artigo integrado e non integrado}

Quero dicir con todo isto que a utilización do artigo xunto a nomes propios de lugar non é nin moito menos equiparable en todos os casos. Dende o punto de vista da orixe, hai que distinguir en primeiro lugar entre artigo etimolóxico, como pode ser, por exemplo, o de $O$ Valadouro ou, en castelán, El Escorial, e artigo antietimolóxico

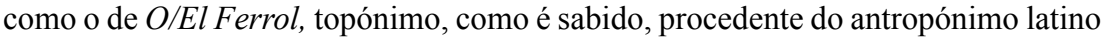


Ferreolus en xenitivo e que, polo tanto, non puido esixir nunca a presenza de tal artigo. Dende outra perspectiva, que poderiamos chamar morfonolóxica, cabe aínda falar de artigo integrado no nome, como Oporto -no español- ou Arrasa (en Cedeira), que xa non se sente como tal artigo, e non integrado, como é o normal (así nos casos anteriores) ${ }^{12}$. Os artigos non integrados, por outro lado, poden ter carácter obrigatorio ou, pola contra, ser opcionais ou expletivos. Tamén existen artigos reais, isto é, que constitúen verdadeiros artigos dende o punto de vista etimolóxico, fronte a artigos falsos ou pseudoartigos, como é, por exemplo, o caso de $O$ Grove, que en realidade debería ser Ogrove. E cabe aínda, finalmente, falar, como veremos na sección 4 , doutros tipos de artigo segundo a función que desempeñan cando van seguidos dun topónimo.

Pois ben, en todo o que segue imos estudar cada un destes tipos por separado comezando -en realidade para desbotalo por quedar fóra do noso tema- polo caso do artigo integrado, o cal en realidade viría a contradicir a tese aquí defendida de que o artigo é unha palabra por si mesmo e, polo tanto, independente, no noso caso, do topónimo ou nome de lugar a que acompaña. Pero a contradición en realidade é só aparente, posto que precisamente dende o momento en que o artigo pasa a formar parte real do topónimo, deixa tamén de sentirse como tal artigo. Realmente ningún hispanofalante interpretaría o $o$ - inicial de Oporto como un verdadeiro artigo, entre outras razóns porque, pola contra, tendería a adaptalo ao español convertendo o devandito topónimo en algo así como *Elporto ou *Elpuerto. Non fai falta notar que isto mesmo ten pasado co artigo árabe de topónimos como Alcalá, Alcántara, Alcañiz, Alcaucín, Alcira, onde tamén se acha totalmente integrado no nome e que xa ninguén sinte con tal artigo ${ }^{13}$.

Fóra dos casos aludidos, existen realmente poucos topónimos que, etimoloxicamente, sexan o resultado da suma -con aglutinación ortográfica incluída- dun artigo e

12 Creo que se trabuca a Academia Española cando na súa recente gramática (2009: 838-839) considera integrado o artigo en casos como La Haya ou El Cairo, ao non admitiren, segundo ela, estes topónimos a intercalación dun adxectivo entre o artigo e o nome: *la populosa Haya, *el variopinto Cairo, fronte, porén, a la vieja Habana, cuxo artigo sería así mesmo integrado. Trátase nestes casos, como veremos máis adiante, do que aquí imos chamar artigo pleonástico, o cal ás veces non permite esa intercalación, pero tampouco - contra a apreciación da propia Academia-ningún complemento despois do nome: notemos que en el Salvador actual o artigo xa non é o pleonástico de El Salvador, senón un recategorizador, ante o cal aquél desaparece.

13 En xeral, a non identificación do artigo -coa conseguinte integración no topónimo- prodúcese con frecuencia no paso dunha denominación toponímica, con artigo, a outra lingua completamente distinta, como acontece, por exemplo, en Norteamérica con algúns topónimos de orixe hispana — tipo Los Ángeles, Las Vegas - no seu paso ao inglés: os falantes, especialmente os que non falan español, xa non interpretan os artigos españois como tales e, polo tanto, non os traducen, pasando así a seren integrados aínda que se sigan escribindo separados. 
un substantivo. Para Galicia, A. Moralejo Lasso (1978: 316) sinala tan só os casos de Ocastro, Abesada, Acernada (xunto co seu plural Acernadas), Afigueira, Ascabanas e Aspallas, aos que hai que engadir Arrasa en Cervo (Cedeira), Arrubial (Castroverde) e varios Arriba ( $<A$ Riba), como, por exemplo, en Chantada. Unha proba máis de que a vogal inicial non se percibe xa como artigo é que algúns destes topónimos - polo menos segundo o Nomenclátor da Xunta- desenvolveron un novo artigo, que neste caso si funciona como tal, como acontece, por exemplo, con A Arrasa de Cedeira e así mesmo con A Arriba en Sillobre (concello de Fene). Así pois, en todos estes casos, só se pode falar da existencia dun artigo dende o punto de vista da etimoloxía, pero que sincrónicamente xa non se sinte nin funciona como tal.

Polo que se refire ás denominacións toponímicas con artigo non integrado, isto é, con artigo propiamente dito, xa observamos que poden levalo obrigatoriamente -aínda que logo haxa contextos en que non o leven, segundo veremos-, como é o caso de A Fonsagrada, O Piñeiro, As Enchousas ou Os Casás, ou, pola contra, úsase opcionalmente ou con carácter expletivo, que é o que acontece con $A$ Coruña, por exemplo.

De acordo coas gramáticas ao uso ${ }^{14}$, levan artigo:

a) Os nomes de ríos, lagos, lagoas, montes, cordilleiras, mares, cabos, puntas e océanos: o Ulla, a Antela, o Xistral, o Cantábrico, o Prioriño, o Índico.

b) Os nomes de arquipélagos, como as Sisargas. Algunha vez tamén os de illas, cando se trata dunha soa: a Cortegada, a Marola.

c) Así mesmo adoitan levar artigo obrigatoriamente os nomes dalgunhas rexións ou bisbarras como $O$ Condado, A Ulloa, ou, en español, la Rioja, la Mancha.

d) Moitos nomes de cidades, vilas, pobos e aldeas sobre todo cando o topónimo procede dun substantivo común: O Freixo, As Penas, A Garda, O Viso, O Pereiro.

e) Algúns nomes de continentes, nacións e países, aínda que nese caso adoita ser potestativo; así, (O) Brasil, (O) Perú, (A) América, (A) Galiza.

f) Finalmente, lévano tamén obrigatoriamente todos os topónimos -isto é, aínda que non leven normalmente artigo- cando van precedidos por un adxectivo: $a$ vella Compostela, o racionalista Ferrol, as contaminadas Pontes, o meu prezado Mondoñedo. Tamén cando levan calquera outro tipo de complemento: o Vigo doutros tempos.

14 Véxase, entre outros, Alcina-Blecua (1975: 563-564) e Freixeiro Mato (2000: 267-269. 


\subsection{Denominacións toponímicas con artigo etimolóxico ou antietimolóxico}

Por artigo etimolóxico deberemos entender un elemento sentido na actualidade como tal artigo e que á vez poida xustificarse dende o punto de vista diacrónico. Normalmente, trátase de sintagmas denominativos cuxo núcleo nominal, convertido en nome propio, procede en realidade dun substantivo común -ou dun adxectivo substantivado- que existiu ou aínda existe como tal na lingua de orixe. A esta categoría pertence a inmensa maioría dos topónimos que hoxe se utilizan con artigo; pensemos, entre outros moitos, en Os Pazos, A Carreira, O Corgo, A Pena, A Lama, O Carballo, O Adro, A Igrexa, O Confurco, A Queiroga, As Nogais, A Cruz do Pouso, As Aceas, O Muiño e un longuísimo etcétera.

Naturalmente, este artigo non se debe confundir co que aparece en sintagmas, tamén denominativos, do tipo o río Sil, a illa de Ons, o cabo Fisterra, a provincia de Pontevedra e mesmo a ría de Ortigueira, o porto de Cariño ou a boca da ría, aínda cando orixinariamente responda a idéntica función: a de verdadeiro actualizador dun substantivo xenérico ou común, que queda así enfocado cara a unha realidade existencial concreta. Naturalmente, esta función desaparece no momento en que ese nome xenérico comeza a sentirse como propio e que, polo tanto, desempeña por si mesmo esa función identificadora ou de conexión directa coa realidade nomeada. Precisamente isto explica que moitos dos topónimos con artigo chegasen a perdelo ou, simplemente, o acepten con carácter expletivo. O primeiro é patente en casos, como, por exemplo, Carballo, Piñeiro e Piñeiros, Teixido, Teixeiro, Castro, Vilariño, Pontedeume, Irixoa, e o segundo dáse, entre outras moitas denominacións, en (A) Pastoriza, que, segundo a súa referencia, se usa con ou sen artigo, ou (O) Cabalo Branco en Ferrol, que unhas veces leva artigo e outras non, (Os) Estados Unidos, etc.

O problema en todo caso está en decidir cándo un nome común pasa a propio neste tipo de sintagmas. Proba desa indecisión é que ás veces podemos ter serias dúbidas á hora de escribir con minúscula ou maiúscula denominacións de lugar como Praza de España ou praza de España, Rúa Maior ou rúa Maior, Illa da Toxa ou illa da Toxa ${ }^{15}$, etc. A cousa, dende logo, non ofrece dúbidas cando o nome en cuestión desapareceu da lingua utilizada no lugar do que é designación (por exemplo, A Graña, Os Sarandós, A Estoxa), ou ben xa non se corresponde con ningunha realidade que teña que ver co significado etimolóxico, como acontece, poñamos por caso, con O Campo do Hospital, entre outras razóns, porque este lugar do concello de Cedeira

15 Parece lóxico que, cando o sintagma está constituído por un nome xenérico e un adxectivo, ambos os dous deben escribirse con maiúscula; habería que escribir, polo tanto, Praza Maior ou Rúa Real e non, como suxire a RAE (Diccionario panhispánico de dudas, s.v. mayúsculas, § 4.10), praza Maior e rúa Real, porque os adxectivos por si mesmos non constitúen ningún topónimo, a menos que estean substantivados, pero non é, naturalmente, este o caso. 
xa non consiste precisamente nun campo -nin, por suposto, alí hai, nin semella que houbera, ningún hospital nin no sentido antigo de 'albergue' nin moderno de 'centro de saúde'-, como tampouco en $A$ Capela se está a pensar en ningunha capela ou igrexa. Non é raro, porén, que a realidade que dá nome ao lugar siga existindo ou estando presente, pero entón o nome, convertido tamén en propio, non se refire tanto a esa realidade coma ao lugar que esta ocupa; por iso non é raro chamar A Igrexa ao conxunto poboacional que rodea a igrexa dunha aldea, $O$ Castelo a toda unha zona onde se atopan aínda as ruínas dun castelo, O Cruceiro ao lugar onde realmente se atopa un cruceiro, etc. O mesmo diriamos de O Porto do Son, onde segue habendo, obviamente un porto, mais o nome refírese a toda unha poboación ou extensión xeográfica non ocupada exclusivamente polo porto. Pero aínda así o límite -repitonon é doado de establecer dun xeito categórico e depende en todo caso do grao de fixación da denominación de que se trata, así como, sobre todo, do seu modo de designar-que é, como vimos, o que, en definitiva, distingue un nome propio doutro común-, e non tanto da súa transparencia ou xustificación obxectiva.

Destaquemos, finalmente, que -se ben menos numerosos- danse tamén casos de artigo antietimolóxico. Un deles é claramente, como queda dito, o de $\mathrm{O}$ Ferrol, denominación que, aínda hoxe, resulta estraña en Galicia, especialmente entre os veciños da bisbarra ferrolá, onde o natural é dicir Ferrol a secas, como realmente se dixo ata o século XVI, en que aparece historicamente por vez primeira a denominación castelá El Ferrol (segundo os meus datos, en $1526^{16}$ ), que responde case que con toda seguridade a unha intención enfática -poderíase dicir que retórica- para encarecer o valor e importancia estratéxica do lugar e porto sobre todo por parte de organismos oficiais relacionados coa mariña ${ }^{17}$; sen dúbida a forma galega $O$ Ferrol, que aparece escrita moi tardíamente, é con toda probabilidade unha tradución ou imitación da rimbombante denominación oficial en castelán, levada por certo ao extremo da

16 Así se le nun documento notarial dese ano:

Pedro Gallego, grumete, fijo de Diego Ximénez e Leonor Alonso, vecinos del Ferrol: ha de haber de sueldo á ochocientos maravedís por mes. Pagáronsele por el sueldo de cuatro meses, tres mill é doscientos (José Toribio Medina, Imprenta y Encuadernación Universitaria, Santiago de Chile, 1908).

17 Non comparto a explicación -sen dúbida rebuscada e sen ningunha base histórica- de C. Torres (1960: 143 e ss.), segundo quen se trataría máis ben do que aquí chamo un pseudoartigo, ao consideralo derivación dun dominus que, en lugar de sanctus, precedería nun principio a Ferreoli, que -segundo elsería un haxiotopónimo (S. Xiao, patrón de Ferrol, foi martirizado xunto con $S$. Ferreol, quen daría o nome á cidade); así, dun hipotético *Domferrol pasaríase a *Doferrol, cuxa primeira sílaba se chegaría a interpretar como a contracción da preposición de e o artigo $o$. Cómpre, por outra banda, sinalar que o S. Xiao que morreu con S. Ferreol é o de Brioude ou de Vienne e, como sinalan J.J. Burgoa e C. de Aracil (2009) non está claro que o patrón de Ferrol sexa precisamente ese santo; parece, pola contra, que se trata máis ben de S. Xiao de Toledo, cuxa festividade se celebra o 7 de xaneiro, que é o día que se vén celebrando tradicionalmente na cidade naval. 
esaxeración barroquista polos que durante algún tempo a converteron en El Ferrol del Caudillo, que por certo neste caso non tivo tradución ao galego.

Creo que unha explicación parecida debe darse ao caso de Coruña con artigo, sinxelamente porque este topónimo non ten a súa orixe en ningún substantivo común que o galego coñecese xamais. Como é sabido, nos textos latinos medievais aparece baixo as formas Crunna, Cruna ou Crunia e sempre, loxicamente, sen artigo, aínda que cunha excepción: “[...] per honorabilem virum Alfonsum Roderici de la Corunna, canonicum compostellanum, principale, in iisdem literis apostolicis principaliter nominatum. (Justo Martín / Lucas Álvarez: Fontes documentais da Universidade de Santiago de Compostela. Pergameos da Serie BENS do Arquivo Universitario), debido probablemente a que la Corunna representa aquí un apelido, pero que demostra ben ás claras a existencia xa na Idade Media da forma castelá. Non é esta, porén, a primeira vez que aparece o topónimo Coruña con artigo castelán, cousa que corresponde a este outro texto de Alfonso X, do ano1270: “[...] e acabo [Span] la torre dalfaro que començara GRIEGOS hercules que es cabo la crunna" (Estoria de Espanna que fizo el muy noble rey don Alfonsso, ed. de Pedro Sánchez Prieto, Universidad de Alcalá de Henares, Alcalá de Henares, 2002).

Pois ben, a falta de textos galego-portugueses medievais que testemuñen a existencia da forma a Coruña fainos sospeitar que a denominación moderna A Coruña podería responder así mesmo -como o caso de $O$ Ferrol-a unha tradución ou acomodación da denominación castelá La Coruña ao galego. De todos os xeitos, o que semella incontestable é que a forma máis antiga é Cruña sen artigo, que aínda existe hoxe en galego, ben é verdade que se sente como pertencente a un rexistro vulgar ou moi popular ao igual que a variante Curuña.

Á presenza dun artigo antietimolóxico -con características tamén expresivaspenso que responden algunhas denominacións de países, bisbarras ou rexións como O Brasil, O Perú, A China, A Alemaña, A Ulla ou o portuguesismo A Galiza. $\mathrm{O}$ artigo neste caso, empregado sen dúbida con maior frecuencia noutros tempos -por exemplo, no español do Século de Ouro, aínda que probablemente por influxo francés o uso se mantivo ata o século XVIII ${ }^{18}$ - obedece a unha intención enfática de poñer de relevo a extensión ou poderío da nación, pobo ou rexión indicada polo topónimo ${ }^{19}$. Por iso penso que non sería nada estraño que o uso deste artigo en galego, cando é antietimolóxico (por exemplo, nos casos de A Coruña e, sobre todo, $O$ Ferrol), responda en moitos casos a un verdadeiro castelanismo, dado que só en castelán sería dado, noutras épocas, o emprego dese estilo retórico.

18 A RAE (Gramática, § 78.c) observa o perigo que hai de incorrer en galicismo abusando deste uso.

19 Cfr. A. Bello (Gramática, § 869) e R. J. Cuervo (Diccionario, III, s.v. el, la, lo, los, las, § 2.a.ß). 


\subsection{Denominacións con artigo falso}

Polo que atinxe á clasificación en artigo real e falso ou pseudoartigo, pode considerarse en realidade unha subclasificación dos artigos etimolóxicos, na medida en que un artigo real ten a súa orixe nun verdadeiro artigo, como acontece nos exemplos do apartado anterior, pero pode proceder tamén, por deglutinación, dun elemento do topónimo que, nun determinado momento da súa evolución, se interpreta incorrectamente como artigo. Por iso os que chamo pseudoartigos non corresponden senón a topónimos que, na súa orixe, levan $o$ - ou $a$-iniciais. É o caso, xa citado máis arriba, de $O$ Grove -do que existe mesmo a forma castelanizada El Grove-, aínda que nos documentos medievais aparece como Ocobre, Ogobre e Ogrove e, como tal, se conserva aínda para denominar un lugar da parroquia de Vilamor, no concello de Mondoñedo, xunto a outro de San Martiño de Andrade en Pontedeume.

Pero existen, evidentemente, outros casos, como o coñecido de $A$ Golada, citado por A. Moralejo Lasso (1977: 316-317), que se atopa como denominación -agora corrixida baixo a forma Agolada - dun concello de Pontevedra, así como dunha parroquia de Coristanco e dous lugares en Mesía e Infesta, na provincia da Coruña. Precisamente en Coruña cidade atopamos outro caso de artigo falso no nome do polígono chamado A Grela -tamén castelanizado como La Grela-, que en realidade é Agrela, isto é, un diminutivo de agra.

É famoso tamén o caso de A Mahía -castelanizado La Mahía-, hoxe corrixido oficialmente como Amaía, nome, como é sabido, dunha pequena bisbarra próxima a Santiago. Pero hai outros posibles, como, por exemplo, o de $O$ Beco, topónimo cedeirés que moi probablemente se trate dunha mala interpretación de Oveco -se non procede da raíz céltica becc- 'punta'-, e tamén $O$ Milladoiro, procedente do latín humiliatoriu.

\section{Funcións do artigo seguido de topónimo}

Unha cuestión fundamental para o tema que estamos a desenvolver é suliñar que -contra o que parecen dar a entender os tratados gramaticais- non todos os artigos que con carácter obrigatorio ou opcional aparecen nun sintagma denominativo de tipo toponímico desempeñan sempre a mesma función. Pódense, en efecto, destacar tres funcións básicas diferentes e, polo tanto, cabe falar doutros tantos tipos de artigos de acordo con esas funcións, a saber: artigo anafórico, como en o Umia, o recategorizador de, por exemplo, el Madrid de los Austrias ou o Lugo romano, e, finalmente, o pleonástico, que é o que, con carácter obrigatorio ou opcional e etimolóxico ou antietimolóxico, aparece encabezando múltiples topónimos. 


\section{1. $O$ artigo anafórico}

O artigo anafórico é o que se utiliza como presentador de nomes propios correspondentes a accidentes xeográficos, entre os que cabe destacar os de ríos ou correntes de auga en xeral -isto é, os hidrónimos-, así como os de montes, cabos, puntas, golfos, praias, penas, etc., como o Miño, o Sil, a Promontoiro (punta), a Castelo (illa), a Marola (pena). Semellante artigo en realidade apunta -de aí a denominación de anafórico- a un substantivo implícito, que non é outro que o representado polo correspondente corónimo ou nome de clase, é dicir, río, regueiro, cabo, punta, praia, etc. De aí que a forma xenérica do artigo veña dada polo xénero do correspondente corónimo e non pola terminación do topónimo, como acontece noutras ocasións; por iso, se di $o$ Ulla, en masculino porque é un río, ou $a$ Promotoiro, en feminino porque é unha punta da ría de Cedeira. En realidade tales denominacións non veñen ser máis que abreviacións, por eliminación do corónimo, das expresións o río Miño, o río Ulla, a punta Promontoiro.

Esta eliminación do corónimo non sempre é posible, cousa que acontece con frecuencia cando a denominación está constituída polo corónimo seguido dun adxectivo e así, dise sempre o Río Maior, o Río Grande (por exemplo, en Narón en vez de o río Xubia), ata o punto de que o propio corónimo tende a se converter en topónimo - de aí a súa grafía con maiúscula- e, dando un paso máis, se chegue a aglutinar co adxectivo, como é o caso de Rioseco, Riotorto, Montemeao, Arealonga, etc. Algo semellante adoita acontecer cando o corónimo vai seguido do sintagma preposicional de + topónimo, sempre que este non se identifique á súa vez como nome do río ou accidente xeográfico designado -isto é, sempre que non se trate dunha aposición-; por exemplo, a ría de Vigo, os montes da Faladoira, o lago de Doniños, as dunas de Corrubedo, a praia de Vilarrube ${ }^{20}$. Claro que, neste último caso, os sintagmas poden presentar distinto grao de fixación ata o punto de se sentir ás veces o corónimo como verdadeiro nome propio (por exemplo, o Río das Mestas), cousa dende logo evidente cando pasa a ter como referente unha realidade non pertencente á clase indicada polo corónimo, o que acontece, por exemplo, con Río de Janeiro, cuxo referente non é un río, senón unha cidade, ou con Río do Pozo (polígono industrial de Narón).

Ás veces poderíase doadamente confundir o artigo anafórico co que aquí imos chamar pleonástico: A Robaleira, por exemplo, podería entenderse como o resultado da elipse de punta, pero o caso é que a punta Robaleira non se di -nin posiblemente

20 Naturalmente, aquí non me estou a referir á elipse que se pode producir contextualmente, como sería o caso, por exemplo, de

A min gústame máis a praia de Valdoviño que a de Vilarrube. 
se teña dito- nunca, senón, no seu lugar, a punta da Robaleira, o que quere dicir que o artigo de $A$ Robaleira debe de ser pleonástico, aínda que á súa vez teña a súa orixe nun uso anafórico por perda dun substantivo xenérico representado por costa, mar ou outro semellante, habida conta do carácter etimoloxicamente adxectivo de Robaleira; en realidade este nome aplícase hoxe na ría de Cedeira a toda unha zona dentro da cal se atopa a punta en cuestión ${ }^{21}$. De todos os xeitos, unha reduplicación do artigo non sería totalmente estraña; é dicir, de a punta Robaleira pasaríase a a Robaleira, da que, unha vez producida a extensión da súa referencia a todo o contorno da costa, se pasaría novamente a a punta da Robaleira.

Algo semellante é o que debeu de acontecer coa denominación o Río das Mestas, tamén na ría de Cedeira: en realidade as Mestas, que non pode utilizarse por si mesmo como denominación do río, correspóndese etimoloxicamente co sintagma as augas Mestas (< lat. aquas mixtas 'augas mesturadas'), onde augas vén a equivaler semanticamente ao corónimo río, e, finalmente, sobre as Mestas formouse o outro sintagma denoninativo o Río das Mestas.

Cabe notar por certo que Mestas xamais podería interpretarse aquí como nome do río, situación moi distinta á que se dá en sintagmas, formalmente idénticos, do tipo o río de Xubia ou monte de Ancos, onde Xubia e Ancos son verdadeiros nomes das realidades designadas, de modo que podemos utilizar as denominacións $o$ Xubia e o Ancos. Atopámonos, nunha palabra, ante casos de aposición, nos que é á súa vez posible a eliminación da preposición, de modo que as denominacións anteriores poden alternar perfectamente con o río Xubia e o monte Ancos, que representan a construción hoxe preferida tanto en español coma en galego, e neste probablemente por influxo do primeiro, segundo G. Navaza (2004: 154), quen, por outro lado, observa que, non obstante, en documentos medievais, o máis frecuente é a construción apositiva coa preposición de: o río de Miño, o río de Deva, etc., e o que determinou a obrigatoriedade na lingua actual do uso do artigo anafórico -diante dos hidrónimos sobre todo- tivo que ser precisamente a perda desa preposición, perda producida, ao meu modo de ver, probablemente -tanto en español como en galego- para evitar a confusión co uso frecuente desa mesma preposición en sintagmas do tipo a ría de Cedeira ou o coto de Pantín, onde, evidentemente, non funciona como enlace de dous substantivos apostos, senón que introduce un verdadeiro complemento de pertenza.

A obrigatoriedade por certo do artigo anafórico con hidrónimos tanto en español coma en galego actual choca co uso antigo, en que, pola contra, como sinala

21 Véxase Porto Dapena (2008: 98-99). 
Navaza para o galego e antes Cuervo ${ }^{22}$ para o castelán, o hidrónimo utilizábase sen artigo, situación da que hoxe son claro exemplo moitos topónimos compostos -sintagmas denominativos na súa orixe-cun hidrónimo como elemento formativo. Pensemos, por exemplo, en Aranda de Duero, Miranda de Ebro, Pontedeume ou Ribadeo (isto é, Ponte de Eume e Riba de Eo), Ribas de Sil, Xinzo de Limia, etc. Hoxe, non obstante, dado o uso, en sintagmas libres, do artigo diante do hidrónimo (pensemos, por exemplo, en casos como o desbordamento do Lérez, a limpeza do Belelle, etc.) existe a tendencia a incluír en topónimos deste tipo un artigo espurio ${ }^{23}$.

Non hai que esquecer de tódolos xeitos que a obrigatoriedade do artigo con hidrónimos, orónimos e demais nomes propios de accidentes xeográficos non é absoluta, pois, o mesmo que co artigo en calquera outra función, desaparece en casos especiais, como no uso vocativo do topónimo ou, tratándose de hidrónimos, cando van seguidos polos adverbios arriba, adiante ou abaixo ${ }^{24}$, como en

\section{¡Ou Ancos! Cheo de maxestade,}

que dixo Crecente Vega nun poema a este monte de Xubia, ou

\section{Subimos nunha lancha Miño arriba.}

E, xa para rematar este apartado, réstanos responder a unha pregunta, sen dúbida crucial neste traballo: ¿Dada a necesidade do artigo anafórico na utilización de hidrónimos e, en xeral, de nomes propios relativos a accidentes xeográficos, pódese considerar que tal artigo forma parte do nome propio en cuestión? Á parte do evidente status de palabra independente que, como vimos, corresponde a todo artigo -o que por si só nos impide o considerar como unha parte compoñente do nome que acompaña-, é obvio que o artigo que aquí chamo anafórico non se diferencia en realidade do que utilizamos en calquera outro sintagma nominal con núcleo elidido, do tipo, por exemplo, de, con referencia a unha cor, o limón por o verde limón. E en efecto: as expresións o río Eume ou o coto de Ancos son, como dixemos, aposicións unimembres de tipo especificativo en que tanto o corónimo ou substantivo xenérico como o específico teñen idéntica referencia e, polo tanto, o artigo, que incide sobre

22 Cfr. Diccionario, s.v. el, la, los, las, § 2.aץ..

23 Outro caso témolo, en Cedeira, no topónimo Porto de Cabo, que nos rótulos da estrada aparece convertido nun incorrecto Porto do Cabo. Curiosamente, este nome utilízase tamén como nome do río -polo que parece, denominado Cabo, ou quizais mellor Cavo, na antigüidade- en competencia con rio das Mestas, a que antes me referín. Véxase Porto Dapena (2008: 114).

24 Cfr. R. J. Cuervo, loc. cit., § 2.a ... $\alpha \alpha$. 
ambos os dous nomes ${ }^{25}$-o mesmo que en o verde limón-, dalgún xeito apunta precisamente ao substantivo elidido ata o punto de que non falten gramáticos -aínda que non comparto esa opinión- que o consideran o verdadeiro núcleo do sintagma ${ }^{26}$, o que neste caso equivalería a consideralo substituto real do corónimo. Por iso pareceríame máis correcta a posición de F. Lázaro Carreter (1975: 370371), segundo quen o artigo sería neste tipo de sintagmas verdadeiro adxacente, pero non do elemento presente, senón do elidido. Sexa iso como for, do que non cabe ningunha dúbida é de que o artigo que aparece, por exemplo, en $O$ Xallas ou O Limia, que tendemos a escribir con maiúscula, precisamente porque se parte da idea -sen dúbida falsa- de que se trata dun elemento pertencente ao hidrónimo, en realidade non é outro que o que aparece en o río Xallas ou o río Limia, cuxa grafía con minúscula non ofrece, sen embargo, dúbidas porque se interpreta como actualizador exclusivo do substantivo común río.

\section{2. $O$ artigo recategorizador}

Chamo artigo recategorizador, como vimos, ao que aparece en sintagmas do tipo el Madrid de los Austrias, o arzebispal Santiago, o caloroso Ourense ou a vetusta Pontevedra. Trátase dun artigo que pode preceder a calquera topónimo, con tal de que este se refira -mediante un adxectivo ou complemento- a unha parte, aspecto, momento existencial do lugar indicado polo topónimo ou, tamén, a un dos posibles lugares con idéntico nome. Chámoo recategorizador -aínda que quizais lle iría mellor o cualificativo de discriminador ou delimitador- inspirándome en E. Coseriu (1969: 269-270), habida conta de que, segundo este autor, a utilización de nomes propios implicando unha referencia múltipla -como acontece, por exemplo, en plurais do tipo Juanes, Marías, Romas- obedecería a unha recategorización destes, os cales pasarían a ser nomes de clase, isto é, verdadeiros substantivos comúns. Pois ben, de ser isto así, tamén o uso do artigo en casos como os que exemplifico máis arriba implicaría esa mesma recategorización na medida en que os devanditos topónimos pasan, mediante o artigo e outros complementos, a se utilizar cunha referencia concreta fronte a outras posibles. Precisamente por isto, penso que talvez o termo discriminador - de tamén clara inspiración coseriana ${ }^{27}$ - podería resultar máis axeitado.

Estea ou non no certo Coseriu, cousa que discutirei deseguida, a verdade é que un topónimo así empregado se comporta en canto a posibilidades de determinación dun

25 Cfr. J. A. Martínez (1994: 193-194).

26 Así, S. Fernández Ramírez (Gramática, § 141, 1987: 144 e ss), R. Lapesa (en Marcos Marín (1973: IX-XIII)), B. Pottier (1959: 51).

27 Cfr. Coseriu (1969: 304 e ss.). 
xeito moi semellante ao dun verdadeiro substantivo común. De aí que sexa posible dicir, por exemplo, en español las dos Españas, los Madriles ou, en galego,

A esta Galicia non hai quen a recoñeza

Antón anda aló polas Pontevedras

Hai un Lugo intramuros xunto a outro Lugo extramuros

Coñezo ambas as dúas Vilalbas: a de Lugo e a de Madrid.

É dicir, o topónimo admite, en xeral, calquera tipo de determinante, non só o artigo, o cal por certo non é distinto do que antecede a outros nomes propios, mesmo referentes a persoas:

Eu quero aо теи Luis de sempre

Esta non é a Madalena de que me falabas

Na escola hai catro Fernandos.

Pero volvendo ao caso dos topónimos, convén precisar que o uso do artigo depende entón da multirreferencialidade daqueles, a cal pode consistir:

a) En primeiro lugar, como vimos, nunha especie de división ou desdobramento nunha serie de partes, etapas históricas ou aspectos do lugar de referencia, e polo tanto no que Coseriu chama unha delimitación, como é o caso de la España visigoda ou, en galego, a Galicia sueva, o Ourense das burgas, o Rábade de sempre. Notemos que a delimitación non só pode ser de tipo especificativo, como nos exemplos propostos, senón meramente explicativa, ao poñer de relevo unha característica do lugar indicado polo topónimo: en a célebre Compostela, o pintoresco Corcubión, a lembrada Cedeira, o caudaloso Miño, en que o adxectivo, que funciona como un verdadeiro epíteto, se coloca entre o artigo e mais o topónimo, aínda que cabe tamén a posibilidade - sen dúbida de carácter enfático- de que artigo e adxectivo se pospoñan (así, en Granada la bella ou Galicia a sempre esquecida).

b) Así mesmo pode vir dada por casos de multivocidade, baseada no feito de que un topónimo pode corresponder a un lugar de extensión variable, como é, por exemplo, o caso de Cedeira, que se pode entender como vila ou zona urbana, como parroquia e como concello -ou, no pasado, como xurisdición-, incluíndo sempre unhas referencias a outras como nunha especie de círculos concéntricos inscritos os uns nos outros. E así, a semellante posibilidade corresponderían expresións como 
A Cedeira vila non é o mesmo que a Cedeira concello,

contexto no que por certo non disoaría a ausencia de artigo.

c) Outro caso viría representado por expresións consistentes nunha identificación, cousa que se produce cando o topónimo é polivalente, isto é, se utiliza como denominación de lugares diferentes. É o que acontece, por exemplo, en

A Vilaboa de Valdoviño non ten nada que ver coa de Pontevedra nin coa de Culleredo.

Non é infrecuente que o complemento co que se establece a identificación se teña fixado e, polo tanto, pase a formar parte do propio topónimo, que adquire así un carácter composto. Así, en A Pobra do Caramiñal fronte a A Pobra de Trives ou A Pobra do Brollón, cuxo artigo por certo se podería confundir co pleonástico, de aí que tenda a interpretarse como parte do topónimo e se escriba con maiúscula. Tales complementos constitúen o que Coseriu chama identificadores constantes ou usuais, fronte aos ocasionais, como no caso de Vilaboa antes citado. Convén, non obstante, advertir que con identificadores constantes ou usuais é frecuente a desaparición do artigo, como acontece, en Viana do Bolo para se diferenciar, por exemplo, de Viana do Castelo, ou en Vilanova de Lourenzá fronte aos numerosos lugares que reciben o nome de Vilanova. Debe engadirse que aínda no caso de que un topónimo veña acompañado dun complemento identificador ocasional, se este aparece desligado sintacticamente do topónimo -por exemplo, ao expresarse parenteticamente-, o artigo tampouco é necesario; así en

\section{Rosario vive en Vilaboa (Valdoviño).}

d) Tamén este artigo recategorizador aparece en contextos en que o topónimo é obxecto dunha cuantificación, sexa mediante un numeral ou, simplemente, un morfema de plural: las dos Españas, los Madriles, as Pontevedras, antes citados.

Pero volvendo agora á nosa formulación inicial, ¿o artigo recategorizador pode verdadeiramente considerarse nalgún caso parte integrante do topónimo? É evidente que non, entre outras razóns, porque a súa utilización é, como acabamos de ver, normalmente obrigatoria con calquera topónimo "recategorizado" -isto é, aínda que non posúa artigo etimolóxico-dependendo, polo tanto, exclusivamente do contexto. De feito ninguén -que eu saiba- puxo nunca en tea de xuízo ese feito, ata o punto de que, salvo en casos moi puntuais de topónimos con complemento fixado (tipo 
A Pobra do Caramiñal, antes mencionado), ninguén escribiría o devandito artigo con maiúscula e tampouco, obviamente, vería ningunha dificultade en traducilo en caso de falar noutra lingua, de sorte, polo tanto, que, en español, serían perfectamente aceptables:

\section{La Cedeira villa no es lo mismo que la Cedeira ayuntamiento}

La Vilaboa de Valdoviño no tiene nada que ver con la de Pontevedra.

Sen dúbida as dificultades con que, pola contra, moitos aceptarían a Pobra do Caramiñal (de Trives ou do Brollón) derivaríanse -penso- da tendencia, xa antes apuntada, a ver moi probablemente este artigo como pleonástico.

Agora ben, un argumento sen dúbida poderoso a prol da interpretación do artigo recategorizador como un elemento gramatical independente do topónimo a que acompaña témolo precisamente nesa función recategorizadora, por canto que -segundo Coseriu- o topónimo quedaría convertido nun verdadeiro nome de clase ou común, cousa que, efectivamente, parece observarse no seu comportamento sintáctico ao aceptar outros determinantes non esperables cun nome propio. De tódolos xeitos, ¿prodúcese realmente semellante recategorizacción como quere o lingüista romanés? Dende logo, no caso de se producir, non sería nin moito menos equiparable á que, por metonimia, se atopa, por exemplo, en dous Picassos, cuxo referente son as obras do pintor malagueño, ou, por antonomasia, en

\section{Pepiño é un verdadeiro Einstein,}

onde Einstein apunta ás calidades do famoso científico.

Non lle falta razón a E. Bajo Pérez (2002: 62 e ss.) cando argumenta en contra do carácter común ou apelativo dos nomes propios — sexan de persoa ou topónimosen contextos en que implican unha referencia múltiple, como acontece, por exemplo, cando utilizamos un nome propio de persoa en plural en contextos do tipo:

\section{Hay varios Pedros en nuestra clase.}

Esta autora acepta, non obstante, a existencia de recategorización cando o nome alude a partes ou aspectos da persoa ou lugar indicados.

De acordo coa postura de Coseriu, a quen seguen outros autores, como, por exemplo, Moreno Cabrera (1991: 219), o nome propio recategorízase como nome común sinxelamente porque pasa a indicar unha clase de seres caracterizados precisamente 
por teren o mesmo nome ${ }^{28}$. Pero a verdade é que semellante caracterización, ao contrario do que acontecería nun verdadeiro nome común, non pode tomarse como definitorio, pois non constitúe un verdadeiro significado, e non o constitúe porque non responde a ningunha conceptualización ou categorización: nun plural como Pedros, o nome segue carecendo de significado algún, e o único que fai é apuntar directamente a varias persoas en lugar de a unha soa como fai o singular Pedro. Este fenómeno, por certo, pode darse tamén nos nomes comúns de carácter homónimo: se digo, por exemplo, que teño dúas tendas, unha de zapatos e outra para ir de campamento, estareime a referir a obxectos de clases moi distintas cuxa única característica común é posuír idéntico nome en galego, pero en modo algún responden a unha clase conceptual como cando falamos de dúas tendas de campaña, por exemplo. Trátase dun plural especial que podemos chamar homonímico e que, obviamente, non implica ningunha clase de recategorización. En definitiva, penso que tratar de ver na simple pluralidade referencial -isto é, homonímica- dun nome propio un caso de recategorización como nome común implica partir da vella concepción de nome propio como o que corresponde a un só e único obxecto, idea evidentemente falsa.

E o que digo do plural homonímico é aplicable tamén ao que podemos denominar plural meronímico, é dicir, cando este implica unha división en partes do obxecto designado, pluralización que así mesmo se produce en certos substantivos comúns, como en as augas do río por a auga do río, por exemplo. Referíndome máis concretamente ao caso dos topónimos, cando dicimos Ferrol e, con carácter expresivo, os Ferroles estamos apuntando ao mesmo referente, aínda que neste segundo caso véndoo como unha pluralidade de partes homónimas, entre as que podemos destacar, por exemplo, o Ferrol vello ou o Ferrol da Madalena, onde segue sendo tan nome propio como nos outros casos. Como se dixo máis atrás, insisto en que o que distingue un nome común do propio non é o número de referentes, senón a forma como esa referencia se leva a cabo: indirectamente, a través dun significado ou concepto definidor dunha clase, ou directamente sen mediar significado ningún.

Digamos, finalmente, para rematar este apartado, que o talvez mal chamado artigo recategorizador, precisamente por poder aparecer -repito- con toda caste de topónimos, o fai tamén, en principio, con aqueles que, á súa vez, van acompañados dun artigo anafórico ou pleonástico, o cal desaparece dada a incompatibilidade de dous artigos nun mesmo sintagma. Así pois, en o caudaloso Miño o artigo xa non é anafórico, senón recategorizador, e o mesmo hai que observar en a Coruña modernista, ou as contaminadas Pontes de García Rodríguez, onde así mesmo desaparece o artigo pleonástico inicial.

28 Nesta mesma liña parece estar a RAE na súa Nueva gramática de la lengua española (2009: 839). 


\subsection{O artigo pleonástico}

Centrándonos agora neste último, o primeiro que debo advertir é que entendo por artigo pleonástico o que aparece diante dun bo número de topónimos sen outra función aparente que a de indicar o carácter actualizado ou referencial do nome a que acompaña, indicación que, ao corresponder xa de por si -por definición, diríamos-a todo nome propio, resulta pleonástica, e de aí, polo tanto, a denominación. Trátase en realidade do artigo que máis atrás clasifiquei como non integrado tanto de tipo etimolóxico como antietimolóxico. Precisamente a este carácter redundante quizais se deba que este artigo sexa en xeral sentido — en comparación co anafórico e o recategorizador - como máis unido ao topónimo, máis esencial, máis interno e cohesionado con el, ata o punto de que exista unha maioritaria tendencia a consideralo como parte integrante deste, o que á súa vez explica o xeneralizado costume de escribilo tamén con maiúscula ${ }^{29}$. Así, A Coruña, A Estrada, A Penela, As Aceas, O Seixo, O Incio, O Vicedo, Os Caneiros, Os Castros, etc. En realidade o proceso de integración no topónimo ten, efectivamente, graos, e indubidablemente o artigo pleonástico presenta - fronte ao anafórico e recategorizador - un primeiro paso nese proceso, pero sen chegar a se convertir nun verdadeiro artigo integrado, do que se diferencia porque, como imos ver, se segue sentindo como artigo e presenta, xa que logo, o comportamento propio desta categoría gramatical.

Sinalemos, para empezar, que o simple feito de que o artigo pelonástico -aínda naqueles casos en que se considera obrigatorio- se volatilice ou desapareza, como xa vimos, ante a presenza doutro con función anafórica ou, sobre todo, recategorizadora e así mesmo ante a presenza de calquera outro tipo de determinante actualizador, parece falar en contra dese pretendido carácter esencial ou integrado. Pensemos, sen ir máis lonxe, no caso relativamente frecuente de hidrónimos que reciben o nome dun lugar por onde pasan e cuxo topónimo leve artigo pleonástico; así, o río que desemboca en Cedeira chámase o Condomiñas, nome tomado do dun lugar, hoxe desaparecido, chamado As Condomiñas, e o mesmo se pode dicir de o Ferrería, outro río así denominado por pasar por un lugar chamado A Ferrería, en Pantín (Valdoviño): naturalmente, non sería posible $*_{o}$ As Condomiñas nin $*_{o}$ A Ferrería. Hai, por outro lado, múltiples exemplos tamén da desaparición do artigo pleonástico ante outro de tipo recategorizador ou determinante con esta mesma función:

29 E así, por exemplo, a RAE (1999: 34) di a propósito deste artigo que se escribirá con maiúscula cando forme parte oficialmente do nome propio, como en El Salvador, La Zarzuela, La Habana, Las Palmas. Na súa Nueva gramática del español (2009) considera a este artigo como integrado, cando é obligatorio, e non integrado -e polo tanto escrito con minúscula-cando é opcional: (el) Perú, (la) Argentina. 


\author{
Eu non recoñezo esta Coruña \\ Gustariame unha Gudiña menos fría \\ A sorprendente Estaca de Bares \\ Os divertidos Caneiros \\ As Negradas de outros tempos ${ }^{30}$.
}

Nótese, ademais, que neste caso o artigo recategorizador pode non coincidir morfoloxicamente co pleonástico, como acontece, por exemplo, en

A miña querida Somozas /*As miñas queridas Somozas,

en que concorda máis ben co correspondente corónimo, isto é, parroquia, aldea ou outro semellante ${ }^{31}$, mentres que o xénero e número do pleonástico ven dado polo substantivo común do que procede o topónimo ou tamén pola terminación deste, entendido como feminino se acaba en $-a$, e como masculino nos outros casos.

É certo que, por outra banda, a incompatibilidade do artigo pleonástico co recategorizador podería constituír unha baza a prol da súa consideración como elemento integrante do topónimo na medida en que, segundo iso, non sería separable, e non sería separable porque non habería posibilidade de introducir entre el e mais o topónimo ninguna outra palabra, que é por certo o argumento que utiliza a RAE na súa Nueva gramática (2009: 839). Nótese que, en efecto, parece que se pode

30 Non serían, efectivamente, posibles

*Eu non recoñezo esta A Coruña

* Gustariame unha A Gudiña menos fría

*A sorprendente A Estaca de Bares

* Os divertidos Os Caneiros

* As As Negradas de outros tempos.

31 En xeral, cando o elemento especializador ou delimitador é un adxectivo anteposto e o topónimo está en plural, pode darse vacilación entre a concordancia formal ou a ad sensum co corónimo. Esta última solución, non obstante, é a elixida cando o topónimo é suxeito, conserva o artigo pleonástico e o adxectivo funciona como predicado:

As Pontes é feo / *As Pontes son feas,

onde feo apunta sen dúbida a lugar, pobo ou outro substantivo parecido. Penso, polo demais, que na elección do número pode xogar un importante papel o feito de que o topónimo se sinta ou non como un verdadeiro plural. 
pasar, por exemplo, de A Coruña a a incomparable Coruña, por intercalación dun adxectivo; pero isto é tan só aparente, segundo xa queda suxerido anteriormente, pois que, neste último caso, non se trata do mesmo tipo de artigo, dada, como se ve, a súa función recategorizadora, non pleonástica. Así que semella máis lóxico pensar que o proceso debeu de ser máis ben este outro:

\section{a incomparable A Coruña $\rightarrow$ a incomparable Coruña}

por perda do segundo artigo ${ }^{32}$. Non fai falta dicir, por outro lado, que a imposibilidade de introducir entre o artigo pleonástico e mais o nome algún outro elemento non depende propiamente da función do artigo, senón das características mesmas do nome propio que acompaña, ao non admitir este ningún tipo de determinación.

E falando precisamente das características sintácticas deste nome, algo do que non cabe dúbida é de que o artigo pleonástico vén esixido non -como o anafórico e o recategorizador- polas características semánticas do sintagma en que se insire, senón por unha valencia de tipo formal do propio topónimo, circunstancia que, por certo, parece falar tamén a prol do seu pretendido carácter intrínseco respecto ao topónimo. Quero dicir con isto que o uso do devandito artigo depende de trazos exclusivamente idiosincrásicos do topónimo, o cal esixirá ou simplemente permitirá a presenza do artigo ao se realizar no discurso. De aí que haxa topónimos que veñen marcados positivamente en canto á necesidade do artigo (trátase do que chamamos artigo obrigatorio, tipo $O$ Corgo), outros, en troques, levan naturalmente a marca negativa, como, por exemplo, Lugo, Pontevedra, Foz ou Ribadeo, e, finalmente, outros son indiferentes á presenza do devandito apéndice gramatical, caso no que

$32 \mathrm{O}$ artigo pleonástico, porén, parece que non se perde nestes outros casos:

La populosa Los Ángeles

A memorable Las Vegas (ou As Vegas),

fronte a

*La populosa Ángeles

*A memorable Vegas,

o que nos levaría á conclusión de que aquí nos atopamos xa diante dun artigo integrado (aínda que non o sexa ortográficamente) e onde, polo tanto, Los Ángeles e Las Vegas é sentido como un auténtico bloque. A integración, de todos os xeitos, non sería completa, poisque o artigo segue funcionando como tal noutros contexos, perfectamente aceptables:

Nicolás estivo nos Ánxeles

Pancho anda polas Vegas.

Así pois, poderíase falar, todo o máis, dunha semiintegración, pero non dunha verdadeira integración, como por certo quere a Academia Española (1009: 838). 
falamos de artigo opcional ou expletivo como acontece, segundo vimos, con $(A)$ Coruña. Isto suposto, non se pode dicir que o artigo forma parte do topónimo, senón, en todo caso, que ambos os dous constitúen -no caso de que o artigo sexa obligatorio- un sintagma denominativo de carácter fixo.

Repito, non obstante, que, aínda así, a obrigatoriedade neste último é de tódolos xeitos relativa, como vimos de ver, pois de feito o artigo séguese interpretando como tal posto que pode desaparecer nas circunstancias antes sinaladas, isto é, ante a presenza doutro tipo de artigo ou de certos determinantes. Pero hai máis aínda: como sinalaron algúns autore ${ }^{33}$ e aquí queda indicado, calquera artigo -incluído, polo tanto, o pleonástico- é, en principio, incompatible con calquera topónimo -ou nome en xeral- cando funciona no plano apelativo da linguaxe ou, o que é o mesmo, se utiliza en vocativo, cousa, evidentemente, pouco frecuente tratándose de topónimos; pero podemos imaxinar, nunha especie de arranque prosopopeico algo así como

\section{Escoita, Coruña, o meu cantar,}

onde, obviamente, non sería posible usar A Coruña, con artigo.

Despois de todo o dito, cómpre admitir que o artigo pleonástico presenta -como xa se dixo-, un maior grao de cohesión co topónimo que calquera outro artigo, isto é, en función anafórica ou recategorizadora. Pero iso non quere dicir nin moito menos que semellante cohesión teña acadado o punto de que artigo e nome se teñan fusionado constituíndo así ambos os dous o topónimo, cousa que se produce única e exclusivamente no caso, xa visto, do artigo integrado, o cal non se sinte -nin funciona- por certo como tal artigo. Pola contra, direi -para rematar- que existe outro argumento, ao meu ver, decisivo e poderoso a prol da idea de que, en galego, o artigo pleonástico non constitúe, dende logo, ningunha parte do topónimo, argumento que vén dado polo comportamento fonosintáctico do apéndice gramatical, segundo o cal este non se distingue en realidade do artigo en calquera función, mesmo cando acompaña a nomes comúns:

a) Por unha parte, existe a tendencia -aínda que non sempre se manifeste na escritura- a utilizar a variante $l o$ e $l a$ cando o devandito artigo vai precedido por unha palabra rematada en $-s$ ou $-r^{34}$, coa que en certo modo se fonde foneticamente. E así, sendo fieis á pronunciación, teriamos que escribir:

33 Así, Freixeiro (2000: 267), Bajo Pérez (2002: 62).

34 Cfr. Freixeiro (2000: 261). 


\author{
¿Visitache-la Coruña? \\ Vaiche gusta-lo Barqueiro \\ Imos a Vilalba e mai-las Pontes.
}

b) Se a palabra que antecede ao artigo é unha das preposicións $a$, con, de, en e por, o artigo únese con ela formando, como é sabido, unha serie de conglomerados: $a o$ (aos) (pronunciados ó, ós), á (ás), co (coa, cos, coas), do (da, dos, das), no (na, nos, nas) e polo (pola, polos, polas). Pois ben, os mesmos fenómenos de fonética sintáctica prodúcense co artigo pleonástico; é dicir,

\title{
Volverei á Coruña
}

Foise do Vicedo

Non comparemos Vigo coa Coruña

Non fai máis que pensar na Garda

Anda pola Costa da Morte.

Creo que grafías de A Coruña, en O Barqueiro, con O Parrote así como d'A Estrada, n'O Freixo, que algunha vez, sobre todo as primeiras, se utilizan -ou utilizaron-, o único que fan é desfigurar a realidade lingüística.

É evidente que estes últimos argumentos non nos serven para o caso do español, onde, excepción feita do encontro das preposicións $a$ e de coa forma el do artigo, non se producen semellantes conglomerados, nin, por outro lado, o artigo se une encliticamente á palabra anterior. As gramáticas resolven o caso de $a$ ou $d e+e l$, observando precisamente que, cando se trata do artigo dun topónimo, non debe producirse a contracción, de modo que teremos Viene de El Escorial, Vamos a El Fresno. Notemos, non obstante, que isto non pasa de ser un puro convencionalismo ortográfico, xa que na pronunciación se produce realmente a contracción, situación que por certo ás veces se reflicte, malia a regra ortográfica, na escritura: por exemplo, a empresa dos tranvías de Ferrol chamábase -e aínda se chama, pois é hoxe a encargada dos autobuses urbanos- en castelán Tranvías del Ferrol. Así pois, non cabe dúbida de que en español o artigo pleonástico dos topónimos aparece, agás neste caso, absolutamente desligado da palabra que lle precede, circunstancia que axuda a interpretar a súa asociación co topónimo como un auténtico bloque indisociable -e efectivamente se trata, como en galego, dun sintagma denominativo- funcionalmente equivalente a un verdadeiro nome propio e, en consecuencia, o artigo parece que se debe escribir tamén con maiúscula. Non obstante, despois de todo o anteriormente dito, non fai falta insistir no incorrecto 
desta última apreciación, a cal virá, por outro lado, favorecida pola frecuencia con que, aínda sen formar parte do topónimo, o artigo ten que se escribir de feito con maiúscula, dada a cantidade de veces - pensemos, por exemplo, no caso dos rótulos das estradas, direccións postais, cartografía, etc. - en que o sintagma denominativo constitúe un texto en si mesmo e, polo tanto, o artigo aparece en inicial absoluto ou mesmo, tratándose dun texto máis amplo, despois dun punto, tendo, pois, que aparecer con maiúscula. Isto suposto, a conclusión que podemos tirar de todo o dito é que o artigo pleonástico non se escribe con maiúscula porque forme parte dun nome propio, senón máis ben ao revés: pénsase que forma parte do nome propio porque normalmente se atopa escrito con maiúscula. Agora ben, isto que, en principio, non parece ter maior transcendencia, si a ten en realidade á hora de utilizar noutra lingua o topónimo correspondente, cuxo artigo, ao ser interpretado como constituínte daquel, tenderá a pasar sen modificación á lingua receptora, converténdose así -dende logo de forma convencional- nun artigo integrado, isto é, sen se adaptar, ao revés do que acontecería se o devandito artigo se escribise con minúscula, á lingua de chegada.

\section{Conclusión}

Visto todo o dito, creo que a conclusión non pode ser outra que, como sospeitabamos ao principio, o artigo que precede aos topónimos, aínda o que á primeira vista se presenta como máis problemático, o de carácter pleonástico, non constitúe nin moito menos nin en español nin, por suposto, en galego, unha parte ou elemento constituínte do topónimo, senón só e exclusivamente do sintagma denominativo do que este último forma parte. Así pois, denominacións como El Escorial, Los Monegros, el Ebro, los Madriles e o mesmo, en galego, o Lérez, o Pindo, o lonxano Teixido, Os Devesos, A Toxa, O Porto do Son, etc. non son en si mesmo topónimos. O que acontece é que estes, xa sexa porque son nomes de ríos, montes, cabos ou doutros accidentes xeográficos, ou sexa porque levan algún complemento discriminador ou delimitador, ou sexa, en fin, porque así o esixe idiosincrasicamente o propio topónimo, poden vir esixidos -e ás veces tan só permitidos- polo propio topónimo, pero sen formar, evidentemente, parte del, pois, agás no caso de que se ache realmente integrado no nome de lugar, o artigo en calquera das súas funcións é sempre unha palabra morfoloxicamente independente, como creo que quedou suficientemente demostrado. Outra cousa é o aspecto ortográfico, segundo o cal se tende a escribir con maiúscula o artigo pleonástico -ás veces tamén o recategorizador- a non ser cando forma conglomerado cunha preposición precedente ${ }^{35}$. Penso que cando o

35 Segundo a última postura da RAE (2009: 839), escribirase con maiúscula tan só o artigo pleonástico de carácter obrigatorio. 
artigo é recategorizador tal proceder é equivocado, e no caso do pleonástico, se ben eu me inclinaría a favor da utilización así mesmo da minúscula -como fan, sen ir máis lonxe, os portugueses-, a verdade é que o costume xa tan arraigado entre nos de escribilo con maiúscula -en castelán e tamén en galego, penso que por influxo da ortografía española- podería non resultar totalmente desatinado, pois diriamos que axuda dalgún xeito a manifestar graficamente ese carácter enfático que ás veces posúe este artigo e poderíase ó mesmo tempo xustificar por un afán de distinguir ou destacar o carácter fixo do sintagma denominativo fronte ao resto do texto en que se insire.

Por outra banda, cómpre engadir que se o artigo, como parece claro, non é verdadeiro constituínte do topónimo e segue funcionando como tal artigo, nada impide que poida acomodarse ou traducirse á lingua que se estea a empregar, sendo polo tanto perfectamente aceptable la Coruña en castelán, como the Corunna en inglés, la Corogne en francés ou das Coruna en alemán, e así mesmo, en galego, a Rioxa, o Escorial ou as Batuecas. O mantemento, por outro lado, do artigo orixinario, cando este vai con maiúscula, non deixa de ser, de acordo co dito, unha decisión non diría incorrecta, pero sí arbitraria e, xa que logo, dabondo artificial. Así pois, só no caso en que o artigo teña realmente carácter integrado e, polo tanto, xa non se sinta nin funcione como tal artigo, esa tradución ou acomodación sería, dende logo, inviable. Cousa diferente é plantexármonos como ese artigo pleonástico debería aparecer en contextos en que a denominación toponímica se emprega soa, isto é, fóra dun texto ou cadea falada pertencente a unha lingua concreta; pénsese, por exemplo, no caso de Galicia, nos letreiros das nosas estradas: parece natural que nesas circunstancias o topónimo deberá aparecer co artigo galego, é dicir, formando parte do sintagma denominativo fixado como oficial, como A Coruña ou A Garda, por exemplo.

E engadirei, para rematar, que, á vista do aquí exposto, a xa en exceso prolongada e realimentada "guerra do artigo" a propósito de $A / L$ a Coruña, na que tan heroicamente participou aquel rapaz da miña anécdota inicial, convértese en fume de palla ou en puros fogos de artificio moi propios ás veces da loita política.

\section{Referencias bibliográficas}

Alarcos Llorach, E. (1970): Estudios de gramática funcional del español (Madrid: Gredos).

Alarcos Llorach, E. (1994): Gramática de la lengua española (Madrid: RAE / Espasa-Calpe).

Alcina Franch, J. / Blecua, J. M. (1975): Gramática española (Barcelona: Ariel). 
Ariza, M. (1993): “¿Es propio el nombre propio?”, en Alcaide Lara, E. R. / Salguero Lamilar, F. J. / Ramos Márquez, M. M. (coords.), Estudios lingüísticos. En torno a la palabra, 33-40 (Sevilla: Universidad de Sevilla).

Bajo Pérez, E. (2002): La caracterización morfosintáctica del nombre propio (A Coruña: Toxos Outos).

Bello, A. (1972): Gramática de la lengua castellana destinada al uso de los americanos (Caracas: Ediciones del Ministerio de Educación).

Bosque, I. / Demonte, V. (dirs.) (2000): Gramática descriptiva de la lengua española (Madrid: RAE / Espasa-Calpe).

Burge, T. (1973): "Reference and Proper Names", Journal of Philosophy 70, $425-$ 439.

Burgoa, J. J. / De Aracil, C. (2009): "San Julián, patrón de la ciudad de Ferrol”, Estudios Mindonienses 25, 303-318.

Carratalá García, E. (1975): "Sobre el nombre propio en castellano (Amado Alonso y Pedro Henríquez vs. Jespersen y Jakobson)", Anuario de Filología I, 389395.

Coseriu, E. (1969²): Teoría del lenguaje y lingüistica general (Madrid: Gredos).

Correas, G. (1954): Arte de la lengua castellana (Madrid: C.S.I.C.).

Cuervo, R. J. (1987): Diccionario de construcción y régimen de la lengua castellan. Vol. III (Bogotá: Instituto Caro y Cuervo).

Díaz Hormigo, M. T. (1998): "Sustantivos comunes y sustantivos propios”, en La categoría lingüistica sustantivo, 159-167 (Cádiz: Universidad de Cádiz).

Fernández Leboráns, M. J. (1999): “El nombre propio”, en Bosque, I. / Demonte, V. (dirs.), Gramática descriptiva de la lengua española. 1: Sintaxis básica de las clases de palabras, 77-128 (Madrid: Real Academia Española / EspasaCalpe).

Fernández Ramírez, S. (1987²): Gramática española. 3.2: El pronombre. Vol. preparado por J. Polo (Madrid: Arco/Libros).

Freixeiro Mato, X. R. (2000): Gramática da lingua galega, II: Morfosintaxe (Vigo: Edicións A Nosa Terra).

García Gallarín, C. (1998): El nombre propio. Estudios de historia lingüística espanola (Madrid: PatRon).

Gardiner, A. (1940): The Theory of Proper Names (Londres). 
Gary Preur, M. N. (1994): Grammaire du nom proper (Paris: PUF Linguistique nouvelle).

Hernández Alonso, C. (1985): “Lo, ¿artículo o pronombre?”, Anuario de Lingüistica Hispánica I, 115 y ss.

Jonasson, K. (1994): Le nom propre. Constructions et interpretations (Louvin-laNeuve: Ducult).

Kleiber, G. (1992): "Quand le nom propre prend article: les cas de noms propres méthonimiques, French Languages Studies 2, 185-205.

Lapesa, R. (1974): “'El', 'la', 'lo' como antecedente de relativo en español”, en F. Marcos Marín, Aproximación a la gramática española, IX-XVII (Madrid: Cincel).

Lázaro Carreter, F. (1975): "El problema del artículo en español: una lanza por Bello", en Homenaje a la memoria de D. Antonio Rodríguez Moñino, 347-371 (Madrid: Castalia).

Lenz, R. (1935³): La oración y sus partes (Madrid: Centro de Estudios Históricos).

López García, A. (1985): "Lo propio del nombre propio”, Lingüistica Española Actual VII, 37-54.

López García, A. (2000): “Clases de nombres propios”, en G. Wotjak (ed.), En torno al sustantivo y adjetivo en el español actual, 183-189 (Frankfurt am Main: Vervuert).

Lyons, J. (1975): Introducción en la lingüística teórica. Versión española de R. Cerdà (Barcelona: Teide).

Martinet, A. (1978): “La palabra”, en Estudios de sintaxis funcional, 204-223 (Madrid: Gredos).

Martínez, J. A. (1994): “Las construcciones apositivas en español”, en Cuestiones marginadas de gramática española, 173-224 (Madrid: Istmo).

Migliorini, B. (1968): Del nome propio al nome comune (Firence: Leo S. Olschki).

Molino, J. (1982): “Le nom propre dans la langue”, Langages 66, 5-20.

Morala, J. R. (1986): "El nombre propio ¿objeto de estudio interdisciplinar?”, Contextos 8, 49-61.

Moralejo Lasso, A. (1977): Toponimia gallega y leonesa (Santiago de Compostela: Pico Sacro). 
Moreno Cabrera, J. C. (1991): Curso universitario de lingüistica general. Tomo I: Teoría de la gramática y sintaxis general (Madrid: Síntesis).

Navaza, G. (2004): “Os topónimos Acea de Ama e O Xurés", Revista Galega de Filoloxía 5, 141-162.

Porto Dapena, X. A. (1985): “A vueltas de nuevo con el artículo español”, en $A c$ tas del Primer Congreso de Hispanistas de Asia, 147-162 (Seúl: Asociación Asiática de Hispanistas).

Porto Dapena, X. A. (1986): Los pronombres (Madrid: Edi-6).

Porto Dapena, X. A. (2008): “Topónimos costeiros da ría de Cedeira”, Revista Galega de Filoloxía 9, 79-125.

Pulgram, E. (1954): “Theory of Proper Names”, Beiträge zur Namenforschung 5, 165-171.

Real Academia Española (1962): Gramática de la lengua española. Ed. reformada de 1931 (Madrid: Espasa-Calpe).

Real Academia Española (1999): Ortografía de la lengua española (Madrid: Espasa-Calpe).

Real Academia Española (2005): Diccionario panhispánico de dudas (Madrid: Espasa-Calpe).

Real Academia Española (2009): Nueva gramática de la lengua española, 2 vols. (Madrid: Espasa Libros).

Robins, R. H. (1971): Lingüística general. Estudio introductorio (Madrid: Gredos).

Torres, C. (1960): "En torno al nombre y origen de El Ferrol”, Cuadernos de Estudios Gallegos XV, 143 e ss. 